\title{
Vertebrate Palaeoecology of the Pisco Formation (Miocene, Peru): Glimpses into the Ancient Humboldt Current Ecosystem
}

\author{
Alberto Collareta ${ }^{1, *(\mathbb{D}}$, Olivier Lambert ${ }^{2} \mathbb{D}$, Felix G. Marx ${ }^{3,4}$, Christian de Muizon ${ }^{5}$, Rafael Varas-Malca ${ }^{6} \mathbb{D}$, \\ Walter Landini ${ }^{1}$, Giulia Bosio ${ }^{7}$ (D), Elisa Malinverno ${ }^{7}$, Karen Gariboldi ${ }^{1}$ (D), Anna Gioncada ${ }^{1}$ (D), Mario Urbina ${ }^{6}$ \\ and Giovanni Bianucci ${ }^{1}$ (D)
}

1 Dipartimento di Scienze della Terra, Università di Pisa, 56126 Pisa, Italy; walterlandini@gmail.com (W.L.); karengariboldi@gmail.com (K.G.); anna.gioncada@unipi.it (A.G.); giovanni.bianucci@unipi.it (G.B.)

2 D.O. Terre et Histoire de la Vie, Institut Royal des Sciences Naturelles de Belgique, 1000 Bruxelles, Belgium; olivier.lambert@naturalsciences.be

3 Museum of New Zealand Te Papa Tongarewa, Wellington 6011, New Zealand; felix.marx@tepapa.govt.nz

4 Department of Geology, University of Otago, Dunedin 9016, New Zealand

5 Département Origines et Evolution, CR2P UMR 7207, Muséum National d'Histoire Naturelle, MNHN, CNRS, UPMC, Sorbonne-Université, 75005 Paris, France; christian.jourdain-de-muizon@mnhn.fr

6 Departamento de Paleontologia de Vertebrados, Museo de Historia Natural-UNMSM, Jesús María, Lima 15072, Peru; varas.m.r@gmail.com (R.V.-M.); mariourbina01@hotmail.com (M.U.)

check for updates

Citation: Collareta, A.; Lambert, O.; Marx, F.G.; de Muizon, C.;

Varas-Malca, R.; Landini, W.; Bosio, G.; Malinverno, E.; Gariboldi, K.; Gioncada, A.; et al. Vertebrate Palaeoecology of the Pisco Formation (Miocene, Peru): Glimpses into the Ancient Humboldt Current Ecosystem. J. Mar. Sci. Eng. 2021, 9, 1188. https://doi.org/10.3390/ jmse9111188

\section{Academic Editors:}

Francesco Tiralongo, Gioele Capillo and Armando Macali

Received: 30 September 2021

Accepted: 23 October 2021

Published: 27 October 2021

Publisher's Note: MDPI stays neutral with regard to jurisdictional claims in published maps and institutional affiliations.

Copyright: (c) 2021 by the authors Licensee MDPI, Basel, Switzerland. This article is an open access article distributed under the terms and conditions of the Creative Commons Attribution (CC BY) license (https:/ / creativecommons.org/licenses/by/ $4.0 /)$.
7 Dipartimento di Scienze dell'Ambiente e della Terra, Università degli Studi di Milano-Bicocca, 20126 Milan, Italy; giulia.bosio@unimib.it (G.B.); elisa.malinverno@unimib.it (E.M.)

* Correspondence: alberto.collareta@unipi.it

\begin{abstract}
The northward-flowing Humboldt Current hosts perpetually high levels of productivity along the western coast of South America. Here, we aim to elucidate the deep-time history of this globally important ecosystem based on a detailed palaeoecological analysis of the exceptionally preserved middle-upper Miocene vertebrate assemblages of the Pisco Formation of the East Pisco Basin, southern Peru. We summarise observations on hundreds of fossil whales, dolphins, seals, seabirds, turtles, crocodiles, sharks, rays, and bony fishes to reconstruct ecological relationships in the wake of the Middle Miocene Climatic Optimum, and the marked cooling that followed it. The lowermost, middle Miocene Pisco sequence (P0) and its vertebrate assemblage testify to a warm, semi-enclosed, near-shore palaeoenvironment. During the first part of the Tortonian (P1), high productivity within a prominent upwelling system supported a diverse assemblage of mesopredators, at least some of which permanently resided in the Pisco embayment and used it as a nursery or breeding/calving area. Younger portions of the Pisco Formation (P2) reveal a more open setting, with wide-ranging species like rorquals increasingly dominating the vertebrate assemblage, but also local differences reflecting distance from the coast. Like today, these ancient precursors of the modern Humboldt Current Ecosystem were based on sardines, but notably differed from their present-day equivalent in being dominated by extremely large-bodied apex predators like Livyatan melvillei and Carcharocles megalodon.
\end{abstract}

Keywords: cetaceans; East Pisco Basin; elasmobranchs; fossil-lagerstätte; palaeobiology; palaeobiooceanography; palaeoenvironments; Peru-Chile current; Sardinops sagax; vertebrate palaeontology

\section{Introduction}

The coast of Peru is dominated by the Humboldt Current, which branches off the Antarctic Circumpolar Current and flows northwards along the Pacific margin of South America [1]. The Humboldt Current is thought to have originated during the Eocene or Oligocene, following major regional changes like the rise of the Andes and the opening of the Drake Passage that also contributed to Antarctic glaciation [2-6]. Today, its cold waters host an outstandingly productive upwelling system, supporting as much as one-fifth of the global marine fish catch [7-9]. 
The deep-time history of the Humboldt Current Ecosystem is recorded in the Pisco Formation of southern Peru. Three factors make this unit especially relevant. First, its lithology is dominated by diatomites and diatomaceous siltstones [10], which suggests high levels of primary productivity consistent with coastal upwelling [11,12]. Secondly, it was deposited over a time span of at least 7 million years $[13,14]$, and thus provides a long-term palaeoenvironmental record. Finally, and most importantly, it is a globally important vertebrate Lagerstätte marked by exceptional fossil abundance, diversity, and quality of preservation [10,15-31].

Here, we provide the first comprehensive palaeoecological synopsis of the fossil vertebrate assemblages of the Pisco Formation and their implications for the ancient Humboldt Current Ecosystem.

\section{Geological Framework}

\subsection{Geodynamic Setting}

The Pisco Formation is broadly exposed in the East Pisco Basin (EPB) of southern Peru (Figure 1A). It varies in thickness from 200 to $1000 \mathrm{~m}$ and, with interruptions, spans the middle Miocene to lower Pliocene [12,13,32,33]. Diatomaceous mudstones dominate especially the upper part of the formation, but sandstones, siltstones, nodular dolomite, tuffaceous beds, conglomerates, and phosphatic intervals also occur [10,12,15,34].

The EPB is an extensional shelf basin forming part of the Peruvian forearc system [35] and was likely uplifted during the Plio-Pleistocene by the subduction of the aseismic Nazca Ridge [36-40]. Its sedimentary infill is about $2 \mathrm{~km}$ thick and comprises, from oldest to youngest, the Caballas, Paracas, Otuma, Chilcatay, and Pisco formations, topped by Pliocene and Quaternary, largely continental deposits [12,41-44]. These units are bounded by regionally extensive angular unconformities [41], and as such represent alloformations (as defined by the North American Commission on Stratigraphic Nomenclature [45]) or depositional sequences [10]. Prior to uplift, the EPB was a semi-enclosed, shallow embayment with several subdivisions (Figure 1B). The latter alternated between periods of partially restricted circulation and relatively open exposure to the Pacific [41], creating a complex depositional setting including coastal, lagoonal, and shelf palaeoenvironments.

About 60 kilometres south of Nazca lies the Sacaco area, sometimes referred to as the "southern Pisco Basin" [46,47]. The Pisco Formation is commonly thought to occur here as well $[15,44,46,48-50]$. However, the Sacaco area is separated from the EPB proper by a structural high (Cerro Huaricangana and nearby elevations), suggesting that they may reflect distinct (albeit related) depositional settings and palaeoecological scenarios. Pending a better understanding of the tectono-sedimentary relationships between the two areas, we here restricted our analysis to the EPB Pisco Formation only (unless stated otherwise). 

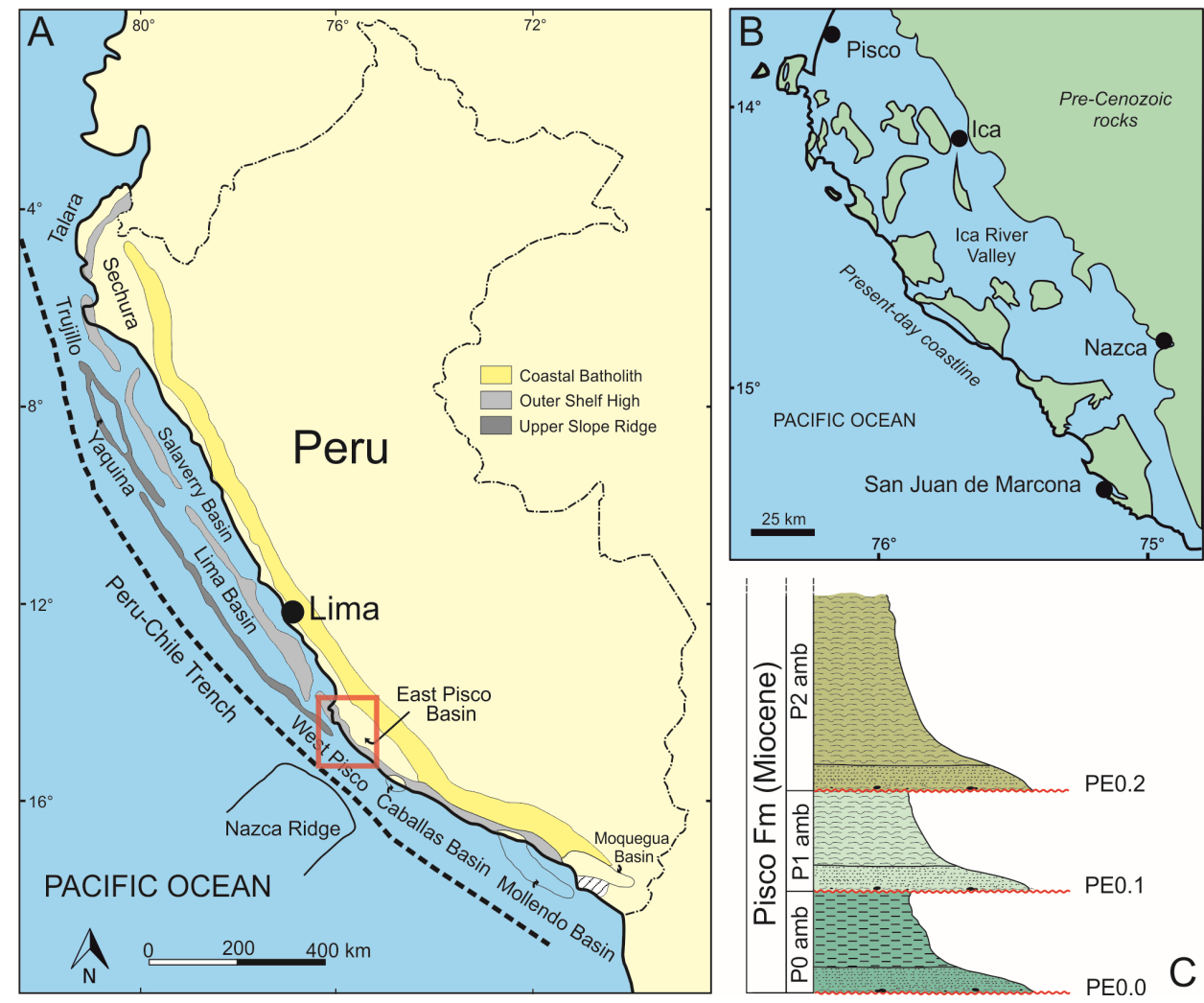

Figure 1. (A) Map of the major Cenozoic sedimentary basins along the coast of Peru. Major structural highs are the Coastal Batholith, the Outer Shelf High and the Upper Slope Ridge. Redrawn and modified from Travis et al. [51] and Thornburg and Kulm [35]. (B) Schematic palaeogeographic map of the East Pisco Basin, showing the areas submerged during the Neogene (redrawn and modified from DeVries and Schrader [52]). (C) Schematic stratigraphic column of the Pisco Formation succession exposed in the East Pisco Basin, and its internal subdivision into allomembers (modified from Di Celma et al. [33]).

\subsection{Stratigraphy of the Pisco Formation in the Lower Ica Valley}

Previous studies have focused on exposures of the Pisco Formation along the lower Ica Valley, which features several hills (locally known as "cerros") with abundant fossil vertebrate assemblages $[25,26]$. The Pisco Formation in this area is about $470 \mathrm{~m}$ thick and comprises three depositional sequences/allomembers named P0, P1, and P2, respectively (Figure 1C) $[10,33,53,54]$. Each allomember records a transgressive trend starting with a Glossifungites ichnofacies, coarse-grained lag deposits and shallow-water sandstones, which then give way to siltstones or diatomaceous mudstones reflecting suspension of organic-rich mud in a highly productive offshore shelf environment [10,33]. Volcanic ash layers, dolomitised mudstones, and thin, fine- to medium-grained sandstones are also locally present. Regressive facies successions are lacking [10]. The age of the P0 allomember has been poorly constrained until recently, but strontium isotope dating now places it in the middle Miocene, between 14.8 and $12.4 \mathrm{Ma}$ [13]. Diatom biostratigraphy and ${ }^{40} \mathrm{Ar} /{ }^{39} \mathrm{Ar}$ ages date P1 to 9.5-8.9 Ma and P2 to 8.5-6.7 Ma [10,14,47,53-55]. Elsewhere, strata assigned to the Pisco Formation are thought to extend into the Pliocene [32,44].

\section{Compilation of the Fossil Vertebrate Dataset}

\subsection{Historical Rationale}

Research on the fossil marine vertebrates from the Pisco Formation (or Pisco-equivalent strata) started in the Sacaco area with the Italian-born geographer and naturalist Antonio Raimondi, who emigrated to Peru in 1850 [56]. Later, Lisson [57] noted the presence of fossil whales in the lower Ica Valley, which a decade later was followed by the first description of the actual deposits and their lithology [58]. Colbert [59] named the first fossil vertebrate 
from the Pisco Formation, the basal delphinidan Incacetus broggii. Finally, Hoffstetter [60] published the first faunal assemblage (including cartilaginous and bony fishes, reptiles, birds, cetaceans, and seals) from the Sacaco area.

International interest in the Pisco Formation soared with the description of numerous marine vertebrates from the late 1970 s onwards $[15,16,20,46,48,50,61-87]$. The richness and exceptional quality of these fossils in turn triggered attempts to quantify the overall association and investigate its taphonomy [17-19,31,34,88].

Most recently, work in the Ica Valley has focused on an interdisciplinary approach to reconstructing the age, palaeoenvironmental setting, preservation, and ecological structure of the Pisco vertebrate assemblages, with an initial focus on the particularly rich sites of Cerro Colorado and Cerro Los Quesos [21,22,25-27,29,53,54,89-91]. This long-term research effort, subsequently extended to other sites and strata [10,13,14,23,24,28,30,33,55,92,93], provides a solid basis for elucidating the interplay of upwelling, volcanic ash fertilization, primary productivity, trophic ecology, diatom deposition, and fossil diagenesis in the ancient Humboldt Current Ecosystem.

\subsection{Field Methods}

For some 15 field seasons, we conducted a detailed census of the vertebrate fossils at the localities of Cerro Colorado, Cerro Los Quesos, and Cerro Submarino [24-26], supplemented by data from Cerro Ballena, Cerro Blanco, Cerro Geoduck, Cerro Hueco la Zorra, Cerro La Bruja, Cerros Cadenas de los Zanjones, Cerros la Mama y la Hija, Corre Viento, Laguna Seca, and Quebrada del Toro Chico. We searched for fossils via systematic surface prospecting and, for each specimen, recorded: (i) its exact location, (ii) a preliminary identification, (iii) a concise description, and (iv) taphonomic observations regarding articulation, completeness, disposition and orientation, bite marks, associated faunal elements (including putative digestive tract content), the presence of a concretion, the extent of erosion, and associated sedimentary structures (see also Bosio et al. [30]); furthermore, whenever possible, we also recorded: (v) basic measurements (including the total length of the skeleton, and the condylobasal length and bizygomatic width of the cranium), and (vi) the degree of fusion of the vertebral epiphyses.

Identifications were often hindered by extensive weathering, especially on steep slopes and windswept flatlands. To ameliorate this problem, we partially excavated several specimens to expose further anatomical detail, and then covered them again with loose sediment to limit further erosion. Particularly informative fossils were collected and deposited in the Museo de Historia Natural de la Universidad Nacional Mayor de San Marcos (MUSM; Lima, Peru). Specimens accessioned or otherwise recorded at the MUSM prior to the beginning of this research effort were also included in our study.

To place our data into temporal context, we used a Jacob's staff and observations on strike and dip to create decimetre-scale sedimentary logs for 16 localities. We then summarised these logs into 15 composite stratigraphic columns (Figure 2) and matched them with our fossil observations (Figure 3). Specimens were placed along the sections with an accuracy ranging from \pm 0.4 to $\pm 3.0 \mathrm{~m}$. The database resulting from this combined taxonomic/taphonomic/temporal census is summarised below, and provided as a series of spreadsheets in Supplementary Table S1 (see also Bosio et al. [30]). 


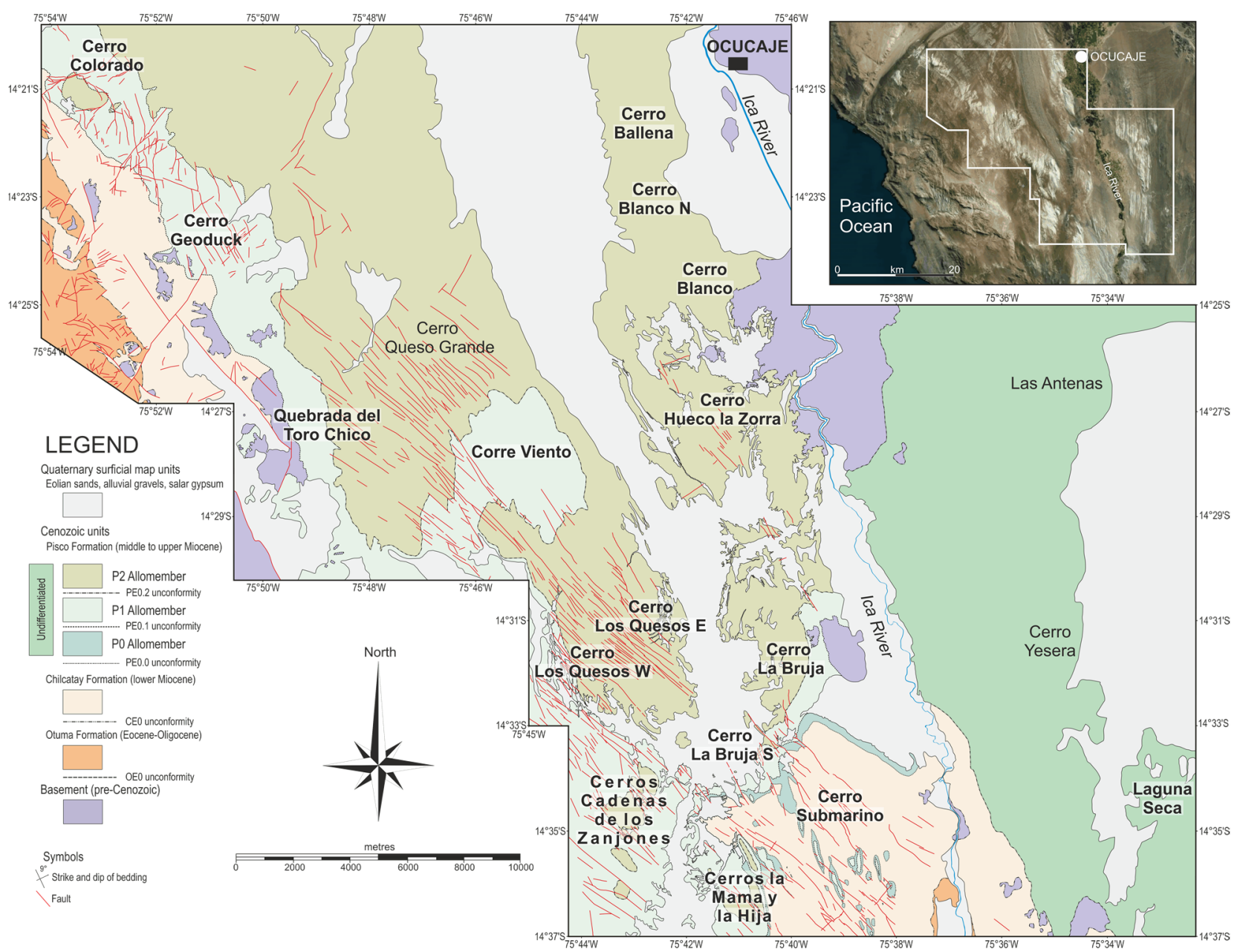

Figure 2. Simplified geological map of the investigated exposures and localities of the Pisco Formation in the Ocucaje area (modified from Bosio et al. [30]). Locality names highlighted in bold indicate the 16 fossil-rich sites where thorough surveys for marine vertebrates were performed (see Supplementary Table S1). 


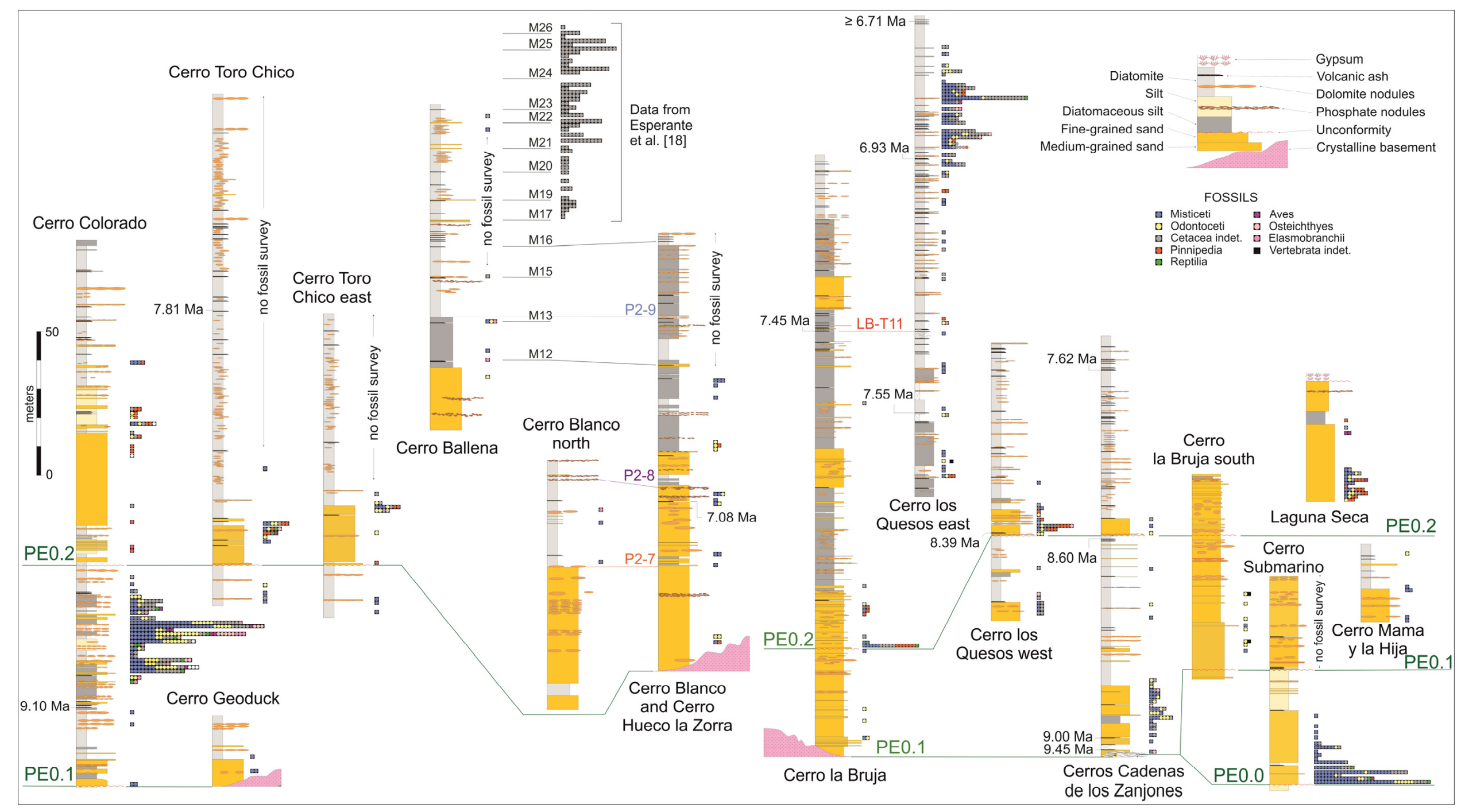

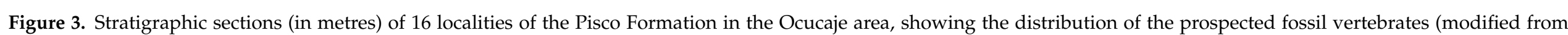

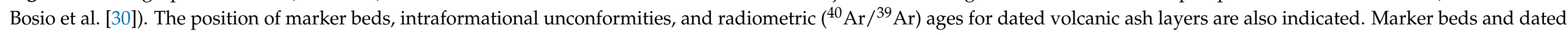
ash layers after Di Celma et al. (in prep.) and Bosio et al. [14]. 


\section{Evolution of the Pisco Vertebrate Assemblage}

Data on the vertebrate assemblage of the scarcely exposed P0 allomember [33] mostly come from Cerro Submarino and the nearby localities of Los Dos Cerritos and Yesera de Amara. In stark contrast with the underlying Chilcatay Formation [33,94,95], baleen whales (mysticetes) are common and include: (i) a large stem balaenopteroid provisionally identified as Pelocetus sp., (ii) the archaic cetotheriid Tiucetus rosae, and (iii) an as yet indeterminate plicogulan (Figure 4A-F) $[10,96,97]$. Toothed whales (odontocetes) are rarer and represented by at least one physeteroid and two kentriodontid-like delphinidans (Figure 4G,H); the holotype of the basal delphinidan Incacetus broggi also likely comes from this unit $[10,24]$.
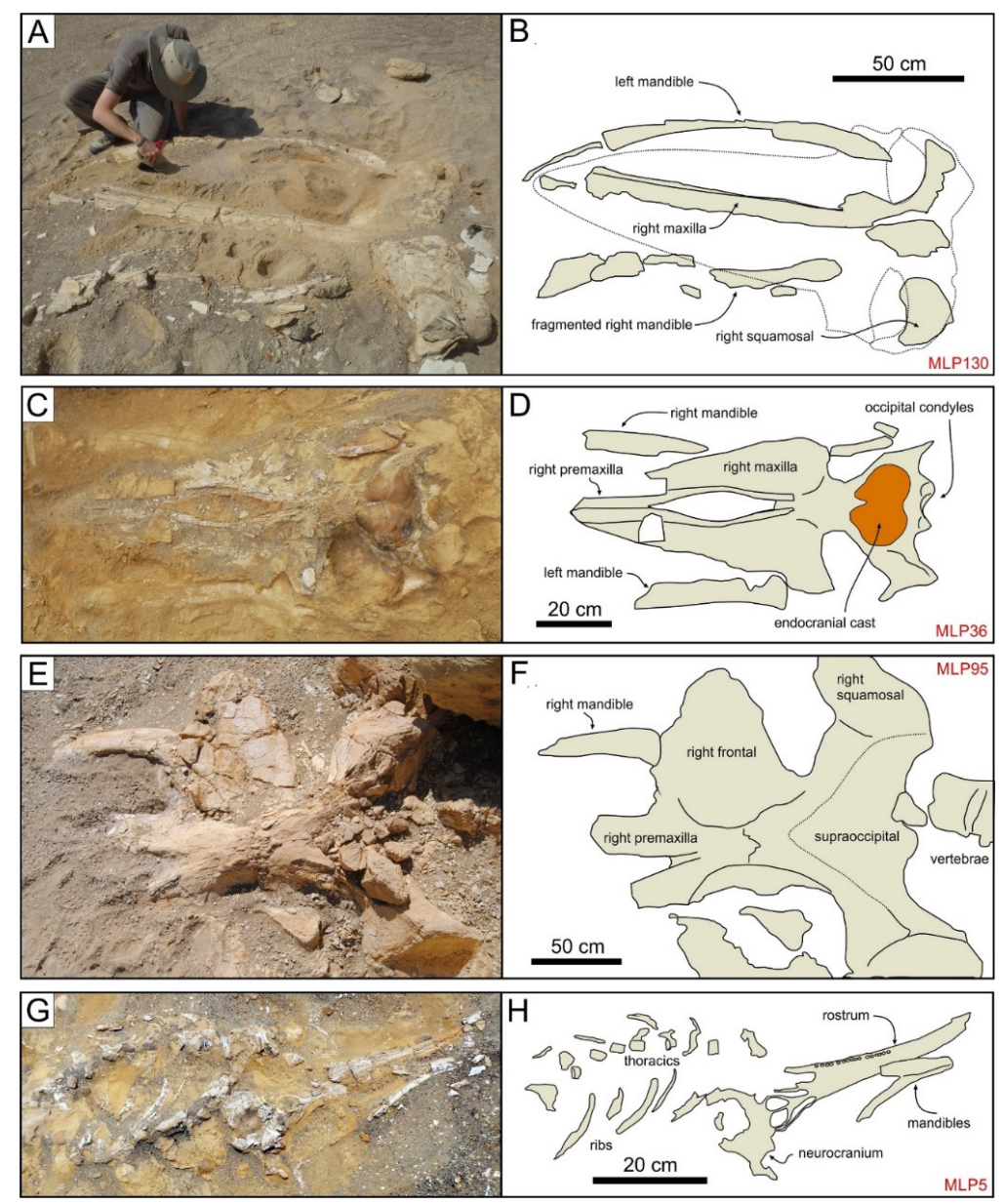

Figure 4. Fossil marine vertebrates from the P0 sequence of the Pisco Formation. (A,B) MLP130, cranium with mandibles of the mysticete cf. Pelocetus sp. from Cerros Yesera de Amara. (C,D) MLP36, cranium with mandibles of the cetotheriid mysticete cf. Tiucetus sp. from Cerro Submarino. (E,F) MLP95, cranium with mandibles of cf. Pelocetus sp. from Cerros Yesera de Amara. (G,H) MLP5, skeleton of Delphinida indet. from Mal Paso. Field photographs (A,C,E,G) and corresponding explanatory line drawings (B,D,F,H).

Fragmentary remains of longirostrine crocodilians, chelonioid sea turtles, and an indeterminate pelagornithid bird are the only non-cetacean tetrapod remains reported so far [24]. Elasmobranch teeth are common, but do not concentrate in any discrete horizon. They include, among others, knifetooth sawfish (Anoxypristis sp.), copper sharks (Carcharhinus brachyurus), mega-toothed sharks (Carcharocles megalodon), "broad-toothed makos" (Cosmopolitodus hastalis), snaggletooth sharks (Hemipristis serra), short-finned makos (Isurus oxyrinchus), and numerous eagle rays (myliobatids) [10,24]. 
P1 hosts an exceptionally abundant and well-preserved vertebrate assemblage studied in great detail at Cerro Colorado and Cerros Cadenas de los Zanjones. Cetaceans abound and range from a relatively common, large cetotheriid and two rarer balaenopterids (Figure 5) [22,27] to physeteroids (Livyatan melvillei and Acrophyseter sp.), ziphiids (Chimuziphius coloradensis and Messapicetus gregarius), inioids (Brujadelphis ankylorostris), pontoporiids (Brachydelphis mazeasi and Samaydelphis chacaltanae), and at least two kentriodontid-like delphinidans (Figure 6) [10,21,80-84,98,99].
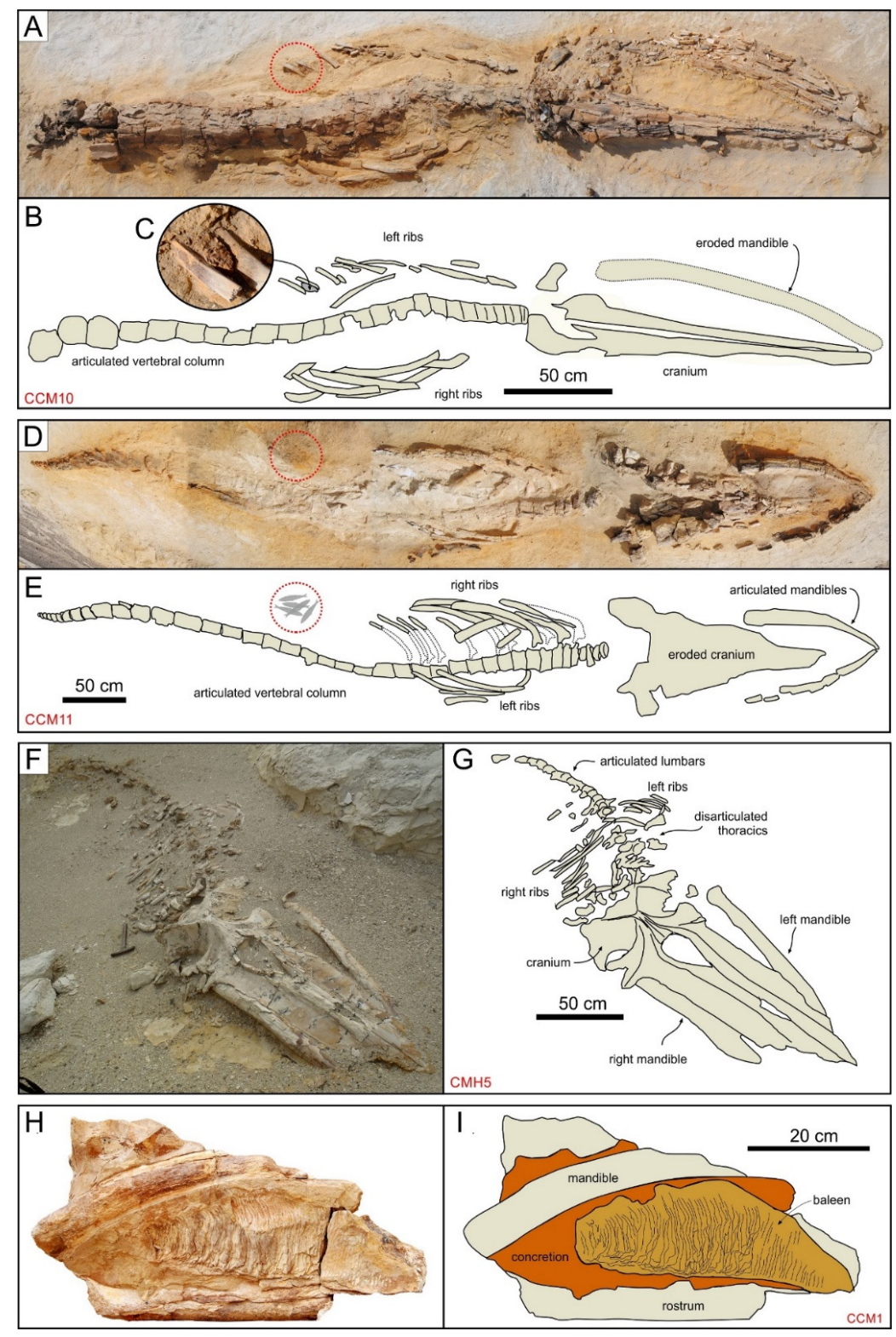

Figure 5. Fossil mysticetes and associated fish remains from the P1 sequence of the Pisco Formation. (A,B) CCM1, skeleton of Cetotheriidae indet. from Cerro Colorado, with fossilised stomach contents (C, skeletal and dermal fish remains) between the left posterior ribs [22]. (D,E) CCM11, skeleton of Cetotheriidae indet. from Cerro Colorado, with fossilised stomach contents (skeletal and dermal fish remains, dashed red circle) behind the right posterior ribs [30]. (F,G) CMH5, skeleton of Cetotheriidae indet. from Cerros la Mama y la Hija. (H,I) CCM1, skeleton of Balaenopteroidea indet. (including fossilised baleen) from Cerro Colorado, preserved within a carbonate concretion (note that only part of the skull is figured here) [27]. Field photographs $(\mathbf{A}, \mathbf{C}, \mathbf{D}, \mathbf{F}, \mathbf{H})$ and corresponding explanatory line drawings (B,E,G,I). 

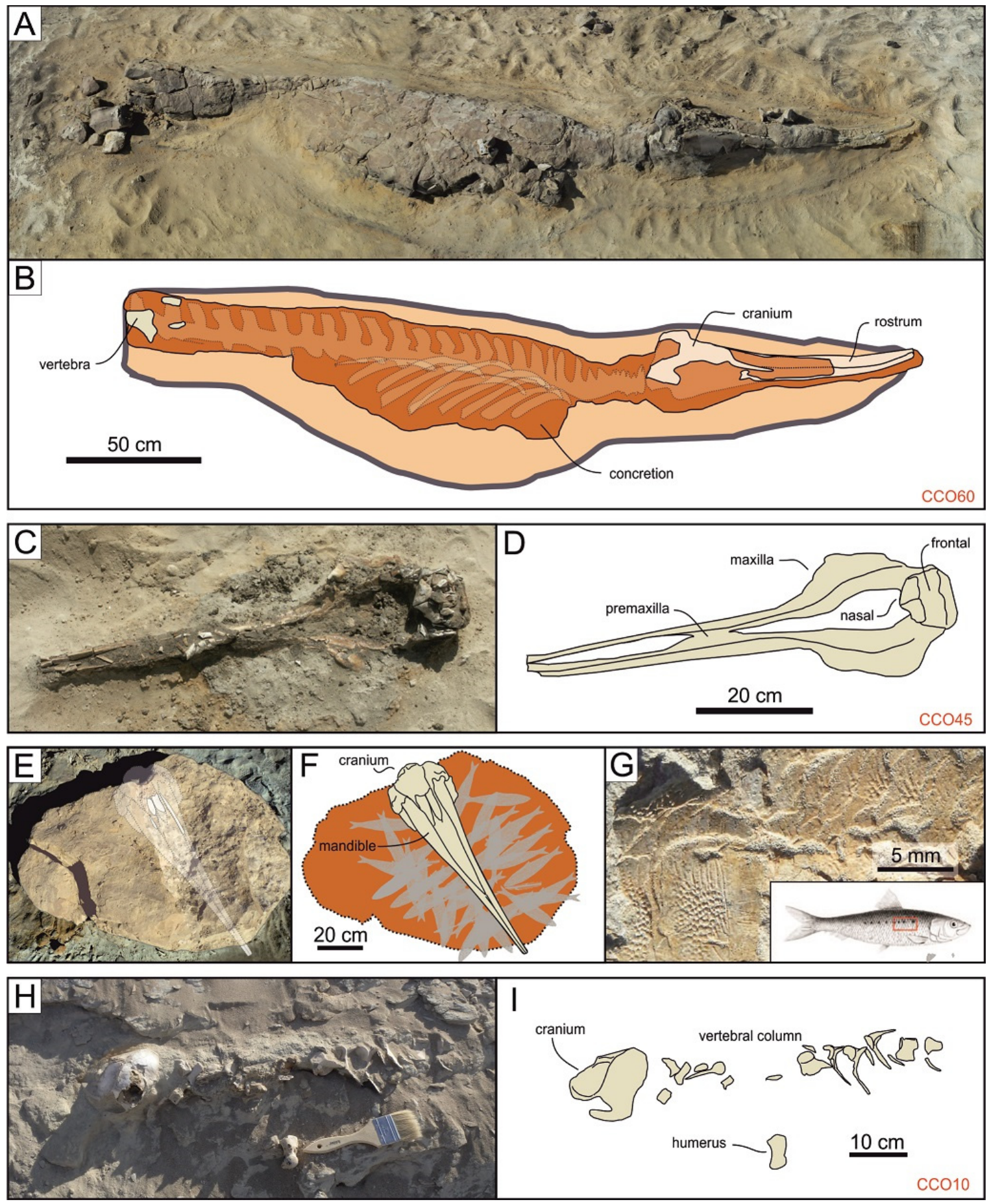

Figure 6. Fossil odontocetes and associated fish remains from the P1 sequence of the Pisco Formation. (A,B) CCO60, skeleton of Messapicetus gregarius from Cerro Colorado, exhibiting a conspicuous carbonate concretion. (C,D) CCO45, skull of M. gregarius from Cerro Colorado. (E,F) CCO38, skeleton of M. gregarius from Cerro Colorado, preserved within a conspicuous carbonate concretion; abundant remains of Sardinops cf. sagax occurring near the skull (G) are interpreted as comprising a fossilised regurgitation [21]. (H,I) CCO10, skeleton of Brachydelphis mazeasi from Cerro Colorado. Field photographs $(\mathbf{A}, \mathbf{C}, \mathbf{E}, \mathbf{G}, \mathbf{H})$ and corresponding explanatory line drawings $(\mathbf{B}, \mathbf{D}, \mathbf{F}, \mathbf{I})$.

Reptiles include the sea turtle Pacifichelys urbinai (Figure 7A,B) and indeterminate crocodilian remains [26,85], while birds are represented by two medium-large sulids (Sula brandi and Sula figueroae), and fragmentary phalacrocoracids and procellariids (Figure 7C) [75]. Elasmobranch teeth are common (Figure 7D,E) and tend to concentrate in two stratigraphic 
intervals (ST-low1 and ST-low2 [90]). The shark assemblage is dominated by carcharhinids (especially Carcharhinus brachyurus), sphyrnids, and various Lamniformes (alopiids, carchariids, lamnids, otodontids, and pseudocarcharhiids), including large macropredators like Cosmopolitodus hastalis, Cosmopolitodus plicatilis, and Carcharocles megalodon. Myliobatiformes are also well represented (Figure 7F), whereas Rhinopristiformes and Squatiniformes are rare [90]. Finally, there are abundant bony fish remains belonging to Sardinops cf. sagax (sometimes in the form of cetacean digestive tract contents $[21,22,30]$ ), as well as ariids, sciaenids, scombrids, and sphyraenids [90].
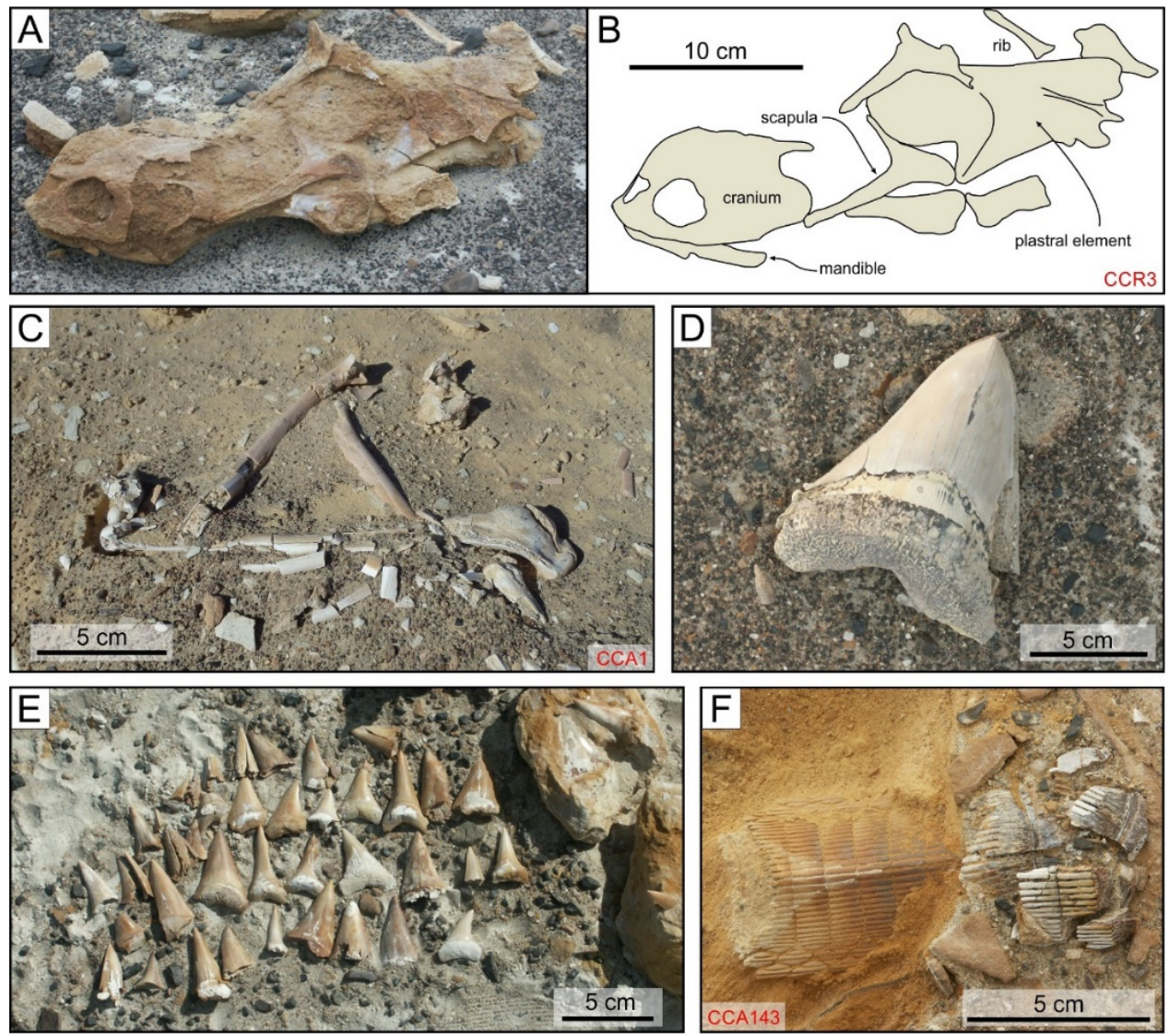

Figure 7. Non-cetacean fossil vertebrates from the P1 sequence of the Pisco Formation. (A,B) CCR3, skeleton of Pacifichelys urbinai from Cerro Colorado. (C) CCA1, postcranial skeleton of Sula figueroae from Cerro Colorado. (D) Tooth of Carcharocles megalodon from Cerro Colorado (unnumbered specimen). (E) Associated tooth set of Cosmopolitodus hastalis from Cerro Colorado (unnumbered specimen). (F) ET22, dental plate of Myliobatidae indet. (Aetomylaeus?) from Cerro Colorado. Field photographs $(\mathbf{A}, \mathbf{C}-\mathbf{F})$ and corresponding explanatory line drawing (B).

The P2 sequence features at least two distinct fossil-rich intervals with different taxonomic compositions. The lower of these, located just above the PE0.2 unconformity, largely corresponds to the "CLB vertebrate level" of Muizon and DeVries [15] and Muizon [16]. It characterises the lowest portion of P2 at various localities (e.g., Cerro Colorado, Cerro La Bruja, and Cerros Cadenas de los Zanjones) and consists of sandstones that locally host reef-like colonies of cirratulid polychaetes [10,100]. The "CLB vertebrate level" marks the first appearance of pinnipeds-specifically, monachines-in the EPB (Figure 8A,B). Mysticetes from this interval are represented by balaenopterids (Figure 9A,B) and the small cetotheriid Piscobalaena nana. Odontocetes include the macroraptorial sperm whale Acrophyseter robustus, the pontoporiid Brachydelphis mazeasi (which persists from the underlying sequence), the kentriodontid-like Atocetus iquensis and Belonodelphis peruanus (both unknown from P1), and some fragmentary delphinoids. 

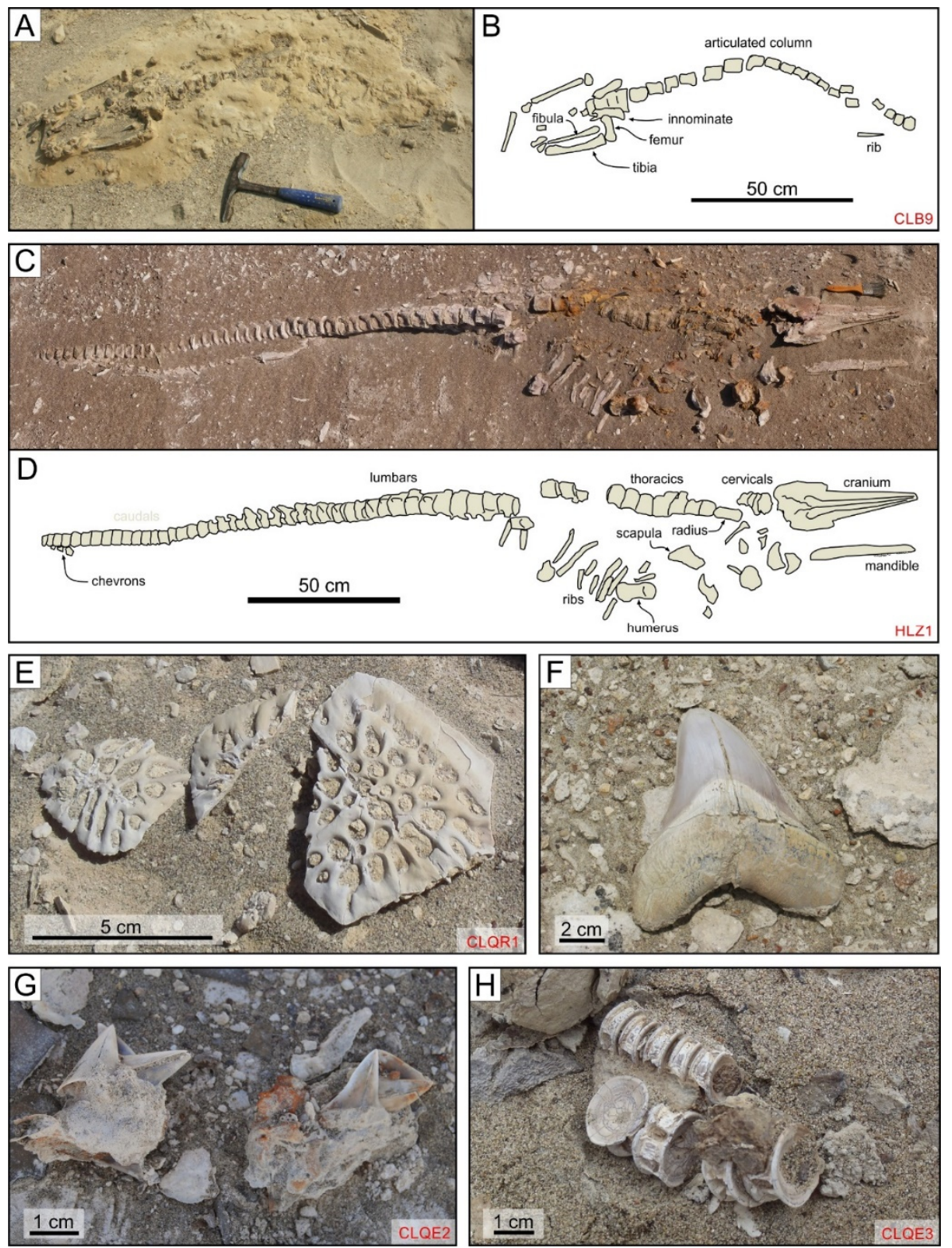

Figure 8. Non-cetacean and odontocete fossil vertebrates from the P2 sequence of the Pisco Formation. (A,B) CLB9, skeleton of Phocidae indet. from Cerro La Bruja. (C,D) HLZ1, skeleton of Phocoenidae indet. from Cerro Hueco La Zorra. (E) CLQR1, dermal plates of cf. Piscogavialis sp. with associated vertebrae from Cerro los Quesos East. (F) Tooth of Carcharocles megalodon from Cerro Los Quesos West (unnumbered specimen). (G) CLQE2, associated tooth set and fragmentary jaws of Cosmopolitodus hastalis from Cerro Los Quesos East. (H) CLQE2, articulated carcharhinid shark vertebrae from Cerro Los Quesos East. Field photographs (A,C,E-H) and corresponding explanatory line drawings (B,D).

Beyond cetaceans, the lower interval has yielded indeterminate cheloniids and crocodilians, sulids, and the oldest known banded penguin, Spheniscus muizoni $[15,78]$. The elasmobranch assemblage is limited to sparse teeth of Lamniformes, possibly representing transient apex predator communities or vagrant individuals (see discussion of the ST-up1 interval in Landini et al. [90]). Finally, bony fishes include aff. Psammoperca sp., triglids, clupeids, and istiophorid billfishes [15].

The vertebrate content of the upper, mostly diatomaceous portion of P2 is exposed at Cerro Ballena, Cerro Blanco, Cerro Colorado, Cerro Hueco la Zorra, and Cerro Los Quesos, among others. Monachine seals are present but uncommon. Numerous mysticete remains represent at least three medium to large balaenopterids, one of which resembles the extant 
humpback whale Megaptera novaeangliae, but there are also some individuals of P. nana (Figure 9C,D,F,G). Odontocetes are less abundant but seemingly more diverse. They include stem physeteroids (Acrophyseter sp. and a large undescribed species $[16,30,80,101]$ ), scaphokogiine kogiids (Scaphokogia cochlearis and Platyscaphokogia landinii [102]), ziphiids (Chavinziphius maxillocristatus, Nazcacetus urbinai, and two unnamed species $[25,79,84])$, the phocoenid cf. Lomacetus ginsburgi, and other porpoise-like delphinoids (Figure 8C,D) [25,30].
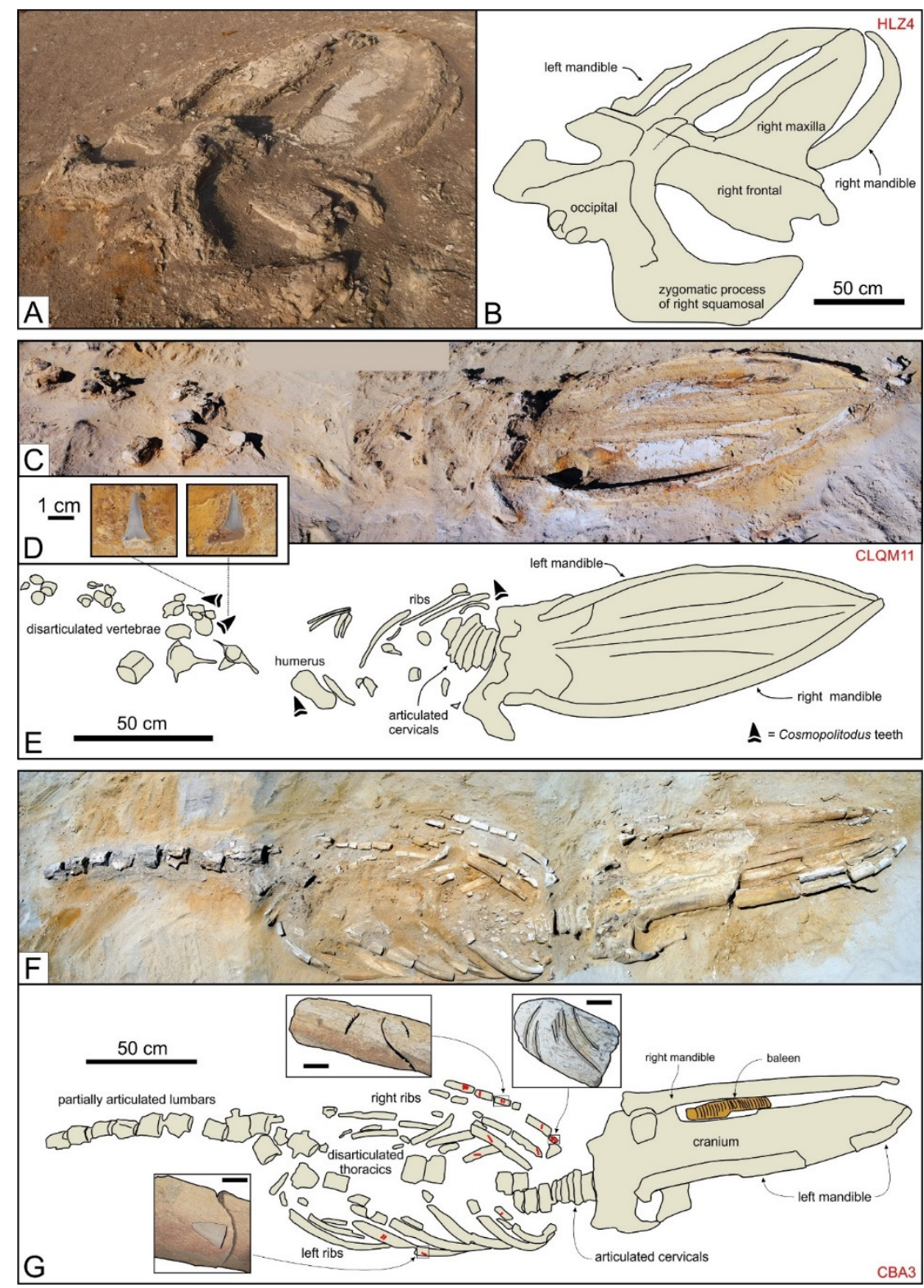

Figure 9. Fossil mysticetes and associated fish remains from the P2 sequence of the Pisco Formation. (A,B) HLZ4, skeleton of Balaenopteridae indet. from Cerro Hueco La Zorra. (C,D) CLQM11, skeleton of Balaenopteridae indet. from Cerro Los Quesos East, with (E) associated teeth of Cosmopolitodus hastalis [30]. (F,G) CBA4, skeleton of Piscobalaena nana (including fossilised baleen) from Cerro Ballena, showing numerous shark bite marks on the ribs (see insets) $[30,103]$ ). Scale bars in the insets equal $1 \mathrm{~cm}$. Field photographs $(\mathbf{A}, \mathbf{C}, \mathbf{D}, \mathbf{F})$ and corresponding explanatory line drawings $(\mathbf{B}, \mathbf{E}, \mathbf{G})$.

The bird and reptile record is limited to a single Phalacrocorax-like cormorant [15,78] and fragmentary remains resembling the gavialoid crocodilian Piscogavialis jugaliperforatus (Figure 8E) [25]. Teeth of a handful of elasmobranchs (e.g., C. megalodon, C. hastalis, Carcharhinus leucas, and myliobatids) often occur as isolated finds (Figure $8 \mathrm{~F}-\mathrm{H}$ ), but are 
sometimes associated with mysticete skeletons (Figure 9C-E) [25,30,90]. Bony fishes are mostly limited to indeterminate material and clupeiform bones and scales representing Sardinops; the latter sometimes occur near mysticete skeletons.

\section{Palaeoecological Reconstruction of the Pisco Vertebrate Assemblage}

The following Section 5.1 proposes a palaeoecological framework for the Miocene vertebrate assemblages from the EPB Pisco Formation. Sections 5.2 and 5.3 further elaborate on the lowest and highest levels of the associated food webs. Finally, Section 5.4 investigates the environmental causes behind the conservative taxonomic structure of the local elasmobranch faunas.

\subsection{A Dynamic Palaeoecological and Palaeoenvironmental Landscape}

Together, vertebrates, macroinvertebrates, and sedimentological data suggest a shallowwater (sub)tropical environment for the sandy strata of the middle Miocene P0 sequence [13,24]. One particularly tell-tale indicator is the extinct shark Hemipristis serra, which commonly occurs in Neogene low-latitude neritic deposits and whose closest extant relative-the snaggletooth shark Hemipristis elongata-inhabits tropical waters $<30 \mathrm{~m}$ deep [104]. Hemipristis serra is relatively common in both P0 and the underlying Chilcatay Formation $[105,106]$, but then vanishes from the local record. Elsewhere (including northern Peru [107]), this species persisted until the Pliocene at least. Its disappearance from the EPB may suggest a strengthening of the cold Humboldt Current, perhaps linked to major palaeoenvironmental changes that coincided with the deposition of P0: the onset of the Middle Miocene Climatic Transition and the emergence of the modern upwelling regime along the Pacific margin of South America [13,24].

Even though P0 is a coastal deposit, numerous fossils of large baleen whales and the occurrence of the common thresher shark (Alopias vulpinus) suggest strong offshore connections [24]. A rich assemblage of hard-shelled benthos [13], eagle rays and bony fish molariform teeth [24] evoke an ecosystem with abundant durophages and a welloxygenated sea bottom. Bite marks on both mysticetes and odontocetes indicate predation or scavenging by sharks [24,30], as also seen in the underlying Chilcatay Formation [105].

The depositional environment of P1, best known from Cerro Colorado, was also mostly shallow marine (though offshore deposition is witnessed by the diatomaceous upper part of the sequence) and home to a rich and ecologically complex vertebrate assemblage (Figure 10) [90]. Microfossils, including diatoms, suggest prominent upwelling [108,109]. The cetacean assemblage is dominated by three species: the pontoporiid Brachydelphis mazeasi, the beaked whale Messapicetus gregarius, and an undescribed cetotheriid resembling (but distinctly larger than) Piscobalaena nana. Brachydelphis mazeasi was small, brevirostrine (sensu McCurry and Pyenson [110]), and likely a suction feeder [86]. If so, its prey would likely have consisted of fish, squid, and crustaceans small enough to be swallowed whole. Unlike its deep-diving extant relatives, $M$. gregarius has been interpreted as a raptorial predator targeting epipelagic schooling fishes like sardines (Sardinops cf. sagax [21]). Stomach contents show that the same applies to the unnamed cetotheriid [22,30]. The large number of specimens attributed to these three species identifies them as regular inhabitants of the late Miocene EPB, although they may have tracked seasonal prey distributions (see Section 5.2). In addition, the presence of extremely young individuals-a foetus of Brachydelphis, and calves of M. gregarius and the cetotheriid [83] (A.C., F.G.M., and G.Bi., pers. obs.) - suggest that the area may have served as a breeding/calving ground. 


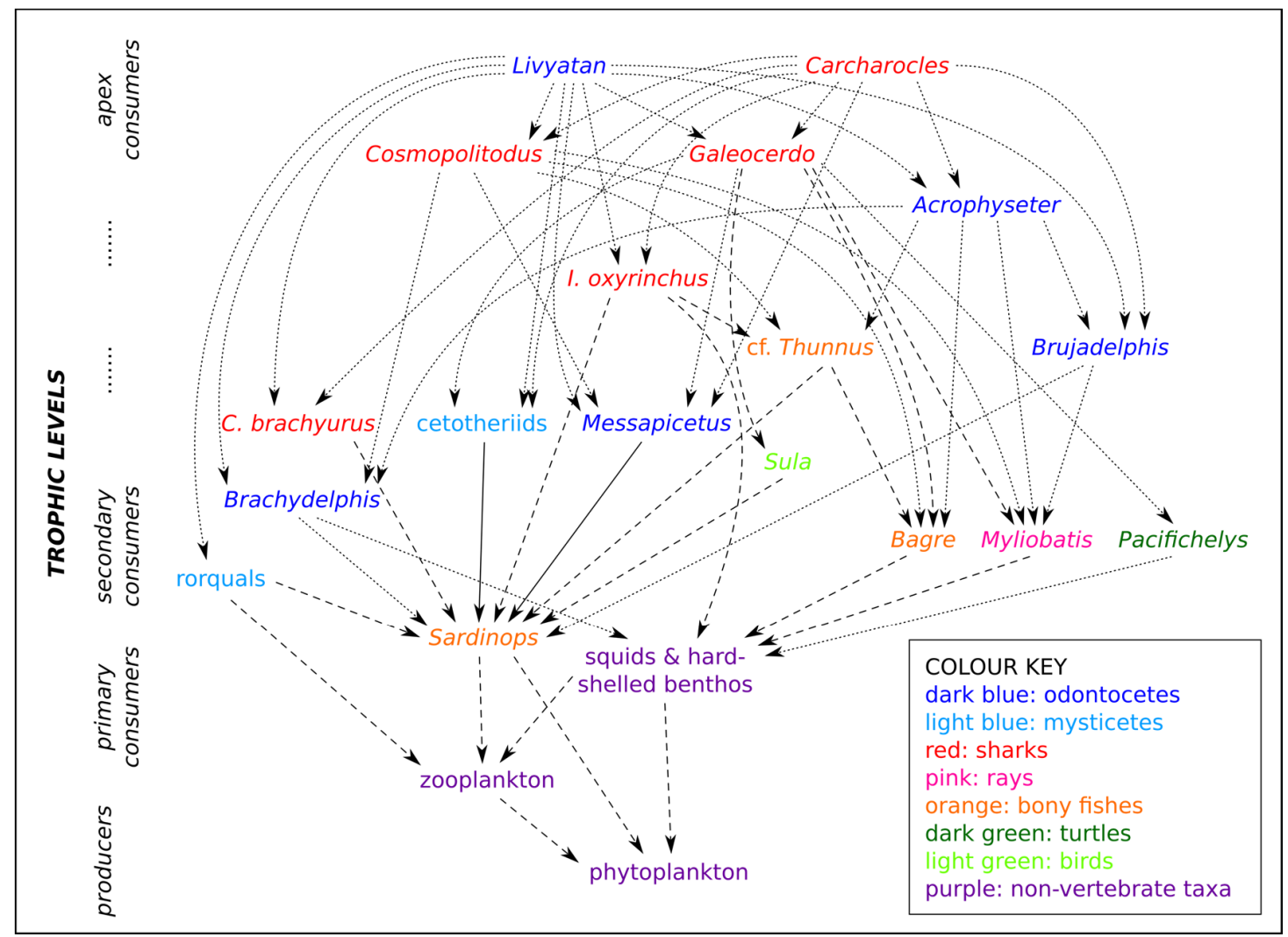

Figure 10. Schematic food web of the Tortonian (early late Miocene) P1 palaeoecosystem. Dotted lines indicate trophic links derived from morphofunctional interpretations and analogy with extant organisms. Solid lines indicate trophic links derived from direct evidence like fossilised digestive tract contents and regurgitations. Dashed lines indicate trophic links based on modern trophic relationships.

Besides Brachydelphis, other delphinidans from P1 (Brujadelphis ankylorostris, Samaydelphis chacaltanae, and two putative kentriodontids) form a relatively minor but still relevant component of the marine mammal assemblage. They considerably vary in rostral proportions and total body length, from $<2 \mathrm{~m}$ in $S$. chacaltanae to at least $3 \mathrm{~m}$ in the largest kentriodontid-like form, perhaps reflecting niche partitioning based on prey size [82]. Stem physeteroids (Acrophyseter sp., Livyatan melvillei) were considerably larger (from 4.0-4.3 m in Acrophyseter to 13.5 or even $16.2-17.5 \mathrm{~m}$ in Livyatan [80]) and likely apex predators alongside sharks such as Galeocerdo cuvier, Cosmopolitodus spp., and Carcharocles megalodon (see Section 5.3). Other similarly-sized cetaceans include at least two balaenopteroids, one of which had finely-fringed baleen consistent with foraging on extremely small prey like copepods [27]. In general, balaenopteroids are rare in the P1 sequence, perhaps reflecting a preference for more pelagic habitats.

The presence of two differently sized sulids (boobies) and a phalacrocoracid (shag/cormorant) evokes a near-shore environment and perhaps a degree of prey size-driven niche segregation between these fish eaters [75]. Several specimens of the sea turtle Pacifichelys urbinai indicate that at least some P1 tetrapods were durophagous [85]. Little is known about the crocodilian, but its mere presence is also consistent with a coastal setting.

Elasmobranch diversity varies throughout P1, with the older of the two main toothbearing intervals (ST-low1) being dominated by a rich community of warm-temperate mesopredators (especially copper sharks, Carcharhinus brachyurus) that used the shallow margins of the EPB as a secondary nursery ground [90,91]. The upper interval (ST-low2) preserves a simpler assemblage of presumably transient apex predators (Section 5.4) that may have exploited the deeper parts of the basin as a seasonal feeding ground. The nursery areas, which likely shifted spatially over time, were hotspots of diversity, disparity, and ecological complexity, and would have been characterised by relatively low predation 
pressure $[90,91]$. Ontogenetic shifts in diet and habitat preferences were likely crucial in promoting the persistence of such fragile elasmobranch communities within the EPB [91].

Bony fishes from P1 remain understudied, but include both pelagic (e.g., Sardinops and cf. Thunnus sp.) and coastal-neritic (e.g., Bagre, Cynoscion, and Sciaenidae indet.) forms [90]. Scales of Sardinops cf. sagax are widespread and sometimes preserved near or inside cetacean skeletons $[21,22,30]$. Sardines plausibly were a keystone species that helped to sustain the vertebrate food web of the Miocene EPB, and the main prey for a broad range of mysticetes, odontocetes, sea birds, sharks, and bony fishes (Section 5.2). The co-occurrence of ariids and sciaenids may indicate the former presence of a river mouth and/or swampy coastal woodlands in the vicinities of Cerro Colorado [90], as also suggested by numerous silicified wood fragments (some of which show Teredolites borings).

Within the lower part of the P2 sequence, the "CLB vertebrate level" evokes a marginal marine environment with abundant fish, bordered by a rocky shore hosting colonies of seals and penguins. The presence of large balaenopterids and billfishes implies strong offshore connections. Acrophyseter, Carcharocles, and Cosmopolitodus were likely the local top predators, and may have targeted smaller marine mammals and penguins on a seasonal basis (e.g., during the pupping season). At Cerro Colorado, for example, isolated teeth of Carcharocles and Cosmopolitodus often occur near pinniped and cetacean remains, perhaps reflecting predation or scavenging [26]. In addition, shark-bitten marine mammal skeletons are relatively frequent in the likely P2 sands exposed at Laguna Seca [30].

Above the lower P2 strata, fossil abundance again peaks in the diatomaceous package at the top of Cerro Los Quesos and roughly correlated horizons at localities such as Cerro Ballena, Cerro Blanco, and Cerro Hueco La Zorra. Seals are present but relatively uncommon. Balaenopterids belonging to at least three different species dominate the assemblage [10]. There are no obvious calves, contradicting earlier suggestions that these animals may have used the EPB as a breeding ground [111]. Cetotheriids are represented by Piscobalaena nana (also known from the Sacaco area [76]) and generally less common than balaenopterids. This is the inverse of the pattern seen in P1, and suggests even stronger links with the open ocean. The feeding strategy and diet of P. nana remain unclear, with potential prey species ranging from copepods to schooling fish [103].

Odontocetes are also comparatively rare, yet mostly different from those of the "CLB vertebrate level", indicating some degree of faunal turnover. Physeteroids include Acrophyseter sp., a second, larger macroraptorial species, and the first kogiids from the EPB: Platyscaphokogia landinii and Scaphokogia cochlearis $[10,102]$. While P. landinii was plausibly a raptorial feeder, the downwards-pointing, semi-cylindrical, pachyostotic rostrum of Scaphokogia suggests benthic foraging $[102,112,113]$. This interpretation is consistent with Scaphokogia being frequently encountered in shallow-water, near-shore deposits, both in the EPB and in the Sacaco area [114]. Beaked whales are rare, but include at least four species employing different feeding strategies: the suction-feeding crown ziphiid Nazcacetus urbinai, the raptorial stem ziphiid Chavinziphius maxillocristatus, and two unnamed species known only from fragmentary remains $[79,84]$. Pontoporiids and kentriodontids are absent (though Pliopontos occurs in seemingly younger strata of the Sacaco area [48]); they appear to have been locally replaced by small phocoenids (once again the oldest in the EPB), some of which resemble Lomacetus ginsburgi from the Sacaco area $[15,66]$.

Elasmobranchs show little diversity and are mostly limited to large opportunistic apex predators like Carcharhinus leucas, Carcharocles megalodon, and Cosmopolitodus spp. [10,25]. Predation and/or scavenging of cetaceans by these sharks is attested by rare bite marks and the occasional occurrence of isolated teeth near mysticete skeletons [30].

Overall, palaeontological and sedimentological data suggest that the upper portion of P2 was deposited in a relatively distal setting characterised by high diatom productivity $[108,109]$ and pelagic vertebrates with wide home ranges. These strata apparently reflect a deeper environment than is recorded in the underlying P1 sequence and the "CLB vertebrate level", and indeed likely are among the deepest deposits of the Pisco Formation west of the Ica River. Coastal taxa like seals, sulids and Scaphokogia are present but rare, 
suggesting that the top of P2 formed at the transition between the near-shore and pelagic realms. By contrast, the marginal-marine deposits of the Sacaco area have yielded terrestrial carnivorans such as procionids (Cyonasua sp. [115]), marine sloths (Thalassocnus spp. [70]), and greater numbers of Scaphokogia-like kogiids [112] and Piscobalaena nana [76]. As such, they may represent a more coastal equivalent of the upper P2 strata (see age estimates in Ochoa et al. [44]).

\subsection{Was the Late Miocene EPB a Sardine-Based Microcosmos?}

Three observations suggest that the late Miocene food web of the EPB was built on small epipelagic schooling fish (Figure 10): first, exceptionally preserved stomach contents and regurgitations from a beaked whale, two cetotheriids, and a mackerel shark, all of which show that schooling sardines were a common prey item [21,22,30,112]; second, the regional occurrence of boobies [75], pelicans [116], and bronze sharks [90,91], all of which are known to target sardines and anchovies in present-day coastal upwelling settings [117-119]; and, finally, the widespread occurrence of loose cycloid scales resembling those of Sardinops sagax [22].

A similar ecological structure defines the modern Humboldt Current Ecosystem, in which abundant clupeiform fishes-the Peruvian anchoveta, Engraulis ringens, and the Pacific sardine, S. sagax — constitute a major food source [9,120-123]. The same species also sustain the strategically important Peruvian fishery, which at times has produced up to $20 \%$ of the global fish catch from less than $1 \%$ of the total area of the global ocean [9]. The reasons behind these exceptional figures remain largely obscure, with primary productivity along the Peruvian coast being comparable to that of other major upwelling systems [9].

Previous explanations for the apparent decoupling between primary productivity and schooling fish abundance invoked short, efficient food chains, with small fish grazing directly on phytoplankton [7]. More recent data have shown, however, that both the Peruvian anchoveta and the Pacific sardine derive most of their dietary carbon from zooplankton $[120,122]$. Alternative reasons for high fish abundance may lie in: (i) a combination of high primary productivity and weak winds generating optimal growth conditions, (ii) a shallow oxygen minimum zone promoting zooplankton by concentrating its prey and excluding its predators, or (iii) El Niño-induced environmental variability favouring fast-growing organisms like diatoms, euphausiids, and clupeiform fishes, while at the same time inhibiting higher-level predators [9]. Similar mechanisms could plausibly have been at play during the late Miocene [124,125], when high-level predators were remarkably diverse and abundant [126], and thus explain the prominent role of schooling fish in the ancient EPB.

There are no modern analogues for the Miocene EPB along the Pacific coast of South America. Similarities do exist, however, with the Gulf of California: a semi-enclosed, internally subdivided basin with an important sardine fishery, located at the tropical end of an eastern boundary upwelling system [127-130]. Its resident sardines are spawned and attain sexual maturity in the deep waters of the central/southern gulf, but then move to the northern gulf to forage $[127,128]$. This may resemble the situation in the ancient EPB, where lateral advection of plankton $[17,18]$ would have created an ideal feeding ground for adult sardines. Consistent with this idea, fossils of Sardinops cf. sagax from the Pisco Formation tend to be physically mature [21].

\subsection{Carcharocles, Livyatan, and Other Overlords: What Ecological Role?}

The structure of the late Miocene EPB ecosystem likely resembled that of its modern Humboldt Current descendant, but differed in at least one important regard: the presence of gigantic apex predators such as Livyatan melvillei and Carcharocles megalodon.

The ecology of "macroraptorial" sperm whales like Livyatan has been inferred from their functional anatomy, and is thought to have involved biting and tearing or shearing of large prey, rather than suction feeding [20,80,101,131-133]. There is, however, as yet no direct evidence for this idea in the form of bite marks or fossilised stomach contents. 
During the middle and late Miocene, macroraptorial sperm whales ranged in length from ca. $4.0 \mathrm{~m}$ in Acrophyseter to as much as $17.5 \mathrm{~m}$ in Livyatan [80], both of which occur in the Pisco Formation. There are no obvious modern analogues for these animals, with the only large mammal-eating cetacean of today-the killer whale Orcinus orca-being both smaller than the largest macroraptorial physeteroids and largely confined to higher latitudes [134]. Killer whales are also highly social and hunt cooperatively, a pattern that cannot be inferred (or discounted) for macroraptorial sperm whales, given the contrasting social habits of extant physeteroids $[135,136]$. Assuming solitary hunting, Acrophyseter was likely a grip-and-shear predator (sensu Peri et al. [126]) limited to relatively small prey like dolphins, seals, marine sloths, seabirds, and relatively large-sized fishes. By contrast, $L$. melvillei could plausibly have targeted larger species like cetotheriids by means of grip-and-tear feeding (sensu Berta and Lanzetti [137]), and likely overlapped in its diet with C. megalodon, a titanic otodontid shark whose maximum body length likely exceeded $15 \mathrm{~m}[138,139]$.

The feeding habits of C. megalodon have been widely discussed [140-142], also in the context of the late Miocene of Peru [114]. Despite its giant size, bite marks from the Sacaco area suggest that $C$. megalodon targeted relatively small marine mammals like the diminutive cetotheriid Piscobalaena nana and seals [114]. At first sight, this observation may seem at odds with teeth of $C$. megalodon showing lower calcium isotope values, and therefore signs of feeding at a higher trophic level, than the great white shark Carcharodon carcharias [143]. Yet these two findings are in fact consistent: most large marine mammals filter feed on tiny prey like copepods and krill, and thus occupy a low trophic level that results in relatively high calcium isotope ratios; by contrast, seals and small cetaceans tend to be dependent on longer food chains, which in turn are reflected in lower calcium isotope ratios. Overall, we hence suggest that $C$. megalodon was a mammal-eating predator (likely more predominantly so than C. carcharias) targeting small to medium-sized species, rather than the largest whales available as instead evoked elsewhere [140,144].

The coexistence of several megapredators like L. melvillei and C. megalodon may reflect ancient marine mammal size distributions. Baleen whales, in particular, were smaller during the Miocene than they are today, a pattern that only changed with the onset of the Northern Hemisphere glaciation and the extinction of most small species around 3 Ma $[97,145,146]$. Both C. megalodon and Livyatan-like physeteroids may have survived until roughly that time [147-149], when the decline of small mysticetes and various other marine vertebrates deprived them of their major food source [126,150,151].

\subsection{A Refugium of Mackerel Sharks}

Across the SE Pacific, Caribbean, and western Atlantic, Neogene ground sharks (Carcharhiniformes) tend to be more diverse than mackerel sharks (Lamniformes) [90,152]. This pattern may reflect the late Eocene spread of scleractinian coral reefs, which was paralleled by a similar radiation of ground sharks [153]. The P1 shark assemblage from the ST-low1 horizon of Cerro Colorado defies the broader trend by preserving more Lamniformes than Carcharhiniformes [90,91]. The reasons behind this phenomenon remain unclear, but may relate to the cold waters of the Humboldt Current preventing reef growth, as they likely do today $[154,155]$, or to abundant marine mammals helping to sustain a flourishing lamniform fauna, as evoked by the occurrence of bite marks attributed to large mackerel sharks such as Cosmopolitodus on some cetacean skeletons [30]. Either way, the EPB (and perhaps other parts of the Pacific coast of South America) seemingly acted as a refugium, allowing the persistence of a conservative, lamniform-dominated shark fauna. The latter, in turn, likely gave rise to the great white shark, the largest macrophagous lamniform alive today $[15,46,50,156]$.

\section{Conclusions and Perspectives}

Our palaeoecological reconstruction suggests that the Pisco Formation preserves conspicuous traces of a complex ecosystem driven by upwelling and abundant schooling fish. 
As such, it may record an early phase of the modern Humboldt Current Ecosystem. The lower portions of the Pisco Formation (P0) formed in a warm, semi-enclosed, near-shore middle Miocene environment. During the first part of the early late Miocene (P1), high productivity driven by upwelling sustained a diverse assemblage of mesopredators, at least some of which permanently resided in the area and used it as a nursery or breeding/calving ground. Large megapredators like Livyatan melvillei and Carcharocles megalodon dominated the top of the food web. Niche partitioning and ontogenetic shifts in diet likely played key roles in maintaining a diverse and ecologically complex marine vertebrate community. Younger portions of the Pisco Formation (P2) reveal a more open setting bordering a rocky shore with seals and penguins. The marine vertebrate assemblage becomes increasingly dominated by wide-ranging species such as rorquals, but with local differences reflecting distance from the coast. Future research could help to elaborate these findings in several ways:

(1) The P0 strata need to be investigated in greater detail to bridge the gap between the relatively well-known lower and upper Miocene assemblages of the EPB, and understand the impact of the Middle Miocene Climatic Optimum and Middle Miocene Climatic Transition. This will include prospecting additional sites such as Santa Rosa $[59,96]$, the type locality of Incacetus broggi and Tiucetus rosae.

(2) The rich shark assemblage from the ST-low1 interval of Cerro Colorado appears to have formed during a period of relative environmental stability, and as such provides an ideal opportunity to investigate feeding ecology and ontogenetic shifts in diet based on stable isotopes [143]. A similar approach could also be applied to toothed whales, e.g., with a view to corroborating the diet of extinct macroraptorial sperm whales and epipelagic beaked whales.

(3) Despite its prominent ecological role, the deep-time history of the Pacific sardine remains largely obscure $[157,158]$. Abundant Sardinops-like fossils from the Neogene of Ecuador may help to rectify this, and elucidate the origin of the boosted fish productivity associated with the rise of the Humboldt Current Ecosystem.

(4) Correlations between the EPB and the Sacaco area need to be improved to provide a clearer understanding of their respective ecological settings. At present, the radiometric dates from these two areas do not entirely match [96], with those from the lowermost strata of the Sacaco area being several decades old.

(5) Comparisons of the Pisco Formation with coeval deposits elsewhere in the eastern Pacific and the Caribbean are currently sparse and ideally should focus on: (i) the Bahía Inglesa Formation of northern Chile (which shows obvious faunal similarities with both the EPB and the Sacaco area [159]), and (ii) the Miramar Formation and related deposits of northern Peru and Ecuador (which would elucidate the northern extent and impact of the ancient Humboldt Current).

(6) Much systematic work remains to be done on the mysticetes, pinnipeds, and marine reptiles of the EPB, which ultimately will contribute to a more detailed understanding of the Pisco assemblages and their complex ecology.

(7) Finally, a comprehensive assessment of the Palaeogene vertebrate assemblages of the EPB is still wanting. A broader knowledge of the fossil fishes and tetrapods of the Paracas and Otuma formations will elucidate the very roots of the present-day Humboldt Current Ecosystem.

Supplementary Materials: The following are available online at https:/ / www.mdpi.com/article/ 10.3390 /jmse9111188/s1, Table S1. Dataset of fossil marine vertebrates from the Pisco Formation strata exposed at the study sites (precise GPS coordinates of the vertebrate finds are available on request from the authors).

Author Contributions: Conceptualization, A.C. and G.B. (Giovanni Bianucci); methodology, A.C. and G.B. (Giovanni Bianucci); validation, O.L., F.G.M., C.d.M., R.V.-M. and W.L.; investigation, A.C., O.L., F.G.M., C.d.M., R.V.-M., W.L., G.B. (Giulia Bosio), E.M., K.G., A.G., M.U. and G.B. (Giovanni Bianucci); data curation, G.B. (Giovanni Bianucci); writing-original draft preparation, A.C.; writing- 
review and editing, O.L., F.G.M., C.d.M., R.V.-M., W.L., G.B. (Giulia Bosio), E.M., K.G., A.G. and G.B. (Giovanni Bianucci); visualization, A.C., G.B. (Giulia Bosio) and G.B. (Giovanni Bianucci); project administration, O.L. and G.B. (Giovanni Bianucci); funding acquisition, O.L. and G.B. (Giovanni Bianucci). All authors have read and agreed to the published version of the manuscript.

Funding: This study was supported by grants from the Italian Ministero dell'Istruzione dell'Università e della Ricerca (PRIN Project 2012YJSBMK to G.Bi.), by the University of Pisa (PRA_2015_0028; PRA_2017_0032 to G.Bi.), by the Università di Camerino (FAR 2019, STI000102 to C. Di Celma), and by the National Geographic Society Committee for Research Exploration grants (9410-13 to G.Bi.; GEFNE 177-16 to O.L.). The funders had no role in study design, data collection and analysis, decision to publish, or preparation of the manuscript.

Institutional Review Board Statement: Not applicable.

Informed Consent Statement: Not applicable.

Data Availability Statement: Not applicable.

Acknowledgments: Special thanks are due to C. Di Celma for his invaluable contribution in disclosing the stratigraphic architecture of the East Pisco Basin. We also thank C. Tinelli, K. Post, A. AltamiranoSierra, B. Ramassamy, M. Laime-Molina, and E. Ghezzo for their support in gathering and discussing the palaeontological data; W. Aguirre, J. Chauca-Luyo, and P. Giuffra for their assistance in the field; P.P. Pierantoni, G. Molli, G. Sarti, G. Cantalamessa, G. Bagnoli, T.J. DeVries, and A. BenitesPalomino for fruitful discussions about the geology and palaeontology of the East Pisco Basin; R. Salas-Gismondi for his support both in the field and at the Museo de Historia Natural de la Universidad Nacional Mayor de San Marcos (Lima); two anonymous referees for their constructive reviews; M. Mao, K. Wang and C. Huo for valuable editorial assistance; and F. Tiralongo, G. Capillo and A. Macali for editing the "Feature Papers in Marine Biology" Special Issue of JMSE.

Conflicts of Interest: The authors declare no conflict of interest.

\section{References}

1. Karstensen, J.; Ulloa, O. The Peru-Chile Current System. In Encyclopedia of Ocean Sciences, 2nd ed.; Steele, J.H., Turekian, K.K., Thorpe, S.A., Eds.; Elsevier: Amsterdam, The Netherlands, 2009; pp. 385-392.

2. Pfuhl, H.A.; McCave, I.N. Evidence for late Oligocene establishment of the Antarctic Circumpolar Current. Earth Planet. Sci. Lett. 2005, 235, 715-728. [CrossRef]

3. Barker, P.F.; Filippelli, G.M.; Florindo, F.; Martin, E.E.; Scher, H.D. Onset and role of the Antarctic Circumpolar Current. Deep. Sea Res. Part II Top. Stud. Oceanogr. 2007, 54, 2388-2398. [CrossRef]

4. Lagabrielle, Y.; Goddéris, Y.; Donnadieu, Y.; Malavieille, J.; Suarez, M. The tectonic history of Drake Passage and its possible impacts on global climate. Earth Planet. Sci. Lett. 2009, 279, 197-211. [CrossRef]

5. Hill, D.J.; Haywood, A.M.; Valdes, P.J.; Francis, J.E.; Lunt, D.J.; Wade, B.S.; Bowman, V.C. Paleogeographic controls on the onset of the Antarctic circumpolar current. Geophys. Res. Lett. 2013, 40, 5199-5204. [CrossRef]

6. Armijo, R.; Lacassin, R.; Coudurier-Curveur, A.; Carrizo, D. Coupled tectonic evolution of Andean orogeny and global climate. Earth-Sci. Rev. 2015, 143, 1-35. [CrossRef]

7. Ryther, J.H. Photosynthesis and fish production in the sea. Science 1969, 166, 72-76. [CrossRef]

8. Penven, P.; Echevin, V.; Pasapera, J.; Colas, F.; Tam, J. Average circulation, seasonal cycle, and mesoscale dynamics of the Peru Current System: A modeling approach. J. Geophys. Res. 2005, 110, C10021. [CrossRef]

9. Chavez, F.P.; Messié, M. A comparison of eastern boundary upwelling ecosystems. Prog. Oceanogr. 2009, 83, 80-96. [CrossRef]

10. Di Celma, C.; Malinverno, E.; Bosio, G.; Collareta, A.; Gariboldi, K.; Gioncada, A.; Molli, G.; Basso, D.; Varas-Malca, R.; Pierantoni, P.P.; et al. Sequence stratigraphy and paleontology of the upper Miocene Pisco Formation along the western side of the lower Ica Valley (Ica Desert, Peru). Riv. Ital. Di Paleontol. E Stratigr. 2017, 123, 255-273.

11. Suess, E.; von Huene, R. Introduction, objectives, and principal results, Leg 112, Peru continental margin. Proc. Ocean Drill. Program Init. Rep. 1988, 112, 5-44.

12. Dunbar, R.B.; Marty, R.C.; Baker, P.A. Cenozoic marine sedimentation in the Sechura and Pisco basins, Peru. Palaeogeogr. Palaeoclimatol. Palaeoecol. 1990, 32, 235-261. [CrossRef]

13. Bosio, G.; Malinverno, E.; Collareta, A.; Di Celma, C.; Gioncada, A.; Parente, M.; Berra, F.; Marx, F.G.; Vertino, A.; Urbina, M.; et al. Strontium Isotope Stratigraphy and the thermophilic fossil fauna from the middle Miocene of the East Pisco Basin (Peru). J. S. Am. Earth Sci. 2020, 97, 102399. [CrossRef]

14. Bosio, G.; Malinverno, E.; Villa, I.M.; Di Celma, C.; Gariboldi, K.; Gioncada, A.; Barberini, V.; Urbina, M.; Bianucci, G. Tephrochronology and chronostratigraphy of the Miocene Chilcatay and Pisco formations (East Pisco Basin, Peru). Newsl. Stratigr. 2020, 53, 213-247. [CrossRef] 
15. de Muizon, C.; DeVries, T.J. Geology and paleontology of late Cenozoic marine deposits in the Sacaco area (Peru). Geol. Rundsch. 1985, 74, 547-563. [CrossRef]

16. de Muizon, C. Les Vertébrés de la Formation Pisco (Pérou). Troisième partie: Les Odontocètes (Cetacea, Mammalia) du Miocène. Trav. De L'inst. Fr. D'études Andin. 1988, 42, 1-244.

17. Brand, L.R.; Esperante, R.; Chadwick, A.V.; Poma, O.; Alomia, M. Fossil whale preservation implies high diatom accumulation rate in the Miocene-Pliocene Pisco Formation of Peru. Geology 2004, 32, 165-168. [CrossRef]

18. Esperante, R.; Brand, L.R.; Chadwick, A.V.; Poma, O. Taphonomy and paleoenvironmental conditions of deposition of fossil whales in the diatomaceous sediments of the Miocene/Pliocene Pisco Formation, southern Peru-A new Fossil-Lagerstätte. Palaeogeogr. Palaeoclimatol. Palaeoecol. 2015, 417, 337-370. [CrossRef]

19. Esperante, R.; Brand, L.R.; Nick, K.E.; Poma, O.; Urbina, M. Exceptional occurrence of fossil baleen in shallow marine sediments of the Neogene Pisco Formation, Southern Peru. Palaeogeogr. Palaeoclimatol. Palaeoecol. 2008, 257, 344-360. [CrossRef]

20. Lambert, O.; Bianucci, G.; Post, K.; de Muizon, C.; Salas-Gismondi, R.; Urbina, M.; Reumer, J. The giant bite of a new raptorial sperm whale from the Miocene epoch of Peru. Nature 2010, 466, 105-108. [CrossRef]

21. Lambert, O.; Collareta, A.; Landini, W.; Post, K.; Ramassamy, B.; Di Celma, C.; Urbina, M.; Bianucci, G. No deep diving: Evidence of predation on epipelagic fish for a stem beaked whale from the Late Miocene of Peru. Proc. R. Soc. B Biol. Sci. 2015, 282, 20151530. [CrossRef]

22. Collareta, A.; Landini, W.; Lambert, O.; Post, K.; Tinelli, C.; Di Celma, C.; Panetta, D.; Tripodi, M.; Salvadori, P.; Caramella, D.; et al. Piscivory in a Miocene Cetotheriidae of Peru: First record of fossilized stomach content for an extinct baleen-bearing whale. Sci. Nat. 2015, 102, 1-12. [CrossRef] [PubMed]

23. Collareta, A.; Landini, W.; Chacaltana-Budiel, C.; Valdivia-Vera, W.; Altamirano-Sierra, A.; Urbina, M.; Bianucci, G. A well preserved skeleton of the fossil shark Cosmopolitodus hastalis from the late Miocene of Peru, featuring fish remains as fossilized stomach contents. Riv. Ital. Di Paleontol. E Stratigr. 2017, 123, 11-22.

24. Collareta, A.; Di Celma, C.; Bosio, G.; Pierantoni, P.P.; Malinverno, E.; Lambert, O.; Marx, F.G.; Landini, W.; Urbina, M.; Bianucci, G. Distribution and paleoenvironmental framework of middle Miocene marine vertebrates along the western side of the lower Ica Valley (East Pisco Basin, Peru). J. Maps 2021, 17, 7-17. [CrossRef]

25. Bianucci, G.; Di Celma, C.; Collareta, A.; Landini, W.; Post, K.; Tinelli, C.; de Muizon, C.; Bosio, G.; Gariboldi, K.; Gioncada, A.; et al. Fossil marine vertebrates of Cerro Los Quesos: Distribution of cetaceans, seals, crocodiles, seabirds, sharks, and bony fish in a late Miocene locality of the Pisco Basin, Peru. J. Maps 2016, 12, 1037-1046. [CrossRef]

26. Bianucci, G.; Di Celma, C.; Landini, W.; Post, K.; Tinelli, C.; de Muizon, C.; Gariboldi, K.; Malinverno, E.; Cantalamessa, G.; Gioncada, A.; et al. Distribution of fossil marine vertebrates in Cerro Colorado, the type locality of the giant raptorial sperm whale Livyatan melvillei (Miocene, Pisco Formation, Peru). J. Maps 2016, 12, 543-557. [CrossRef]

27. Gioncada, A.; Collareta, A.; Gariboldi, K.; Lambert, O.; Di Celma, C.; Bonaccorsi, E.; Urbina, M.; Bianucci, G. Inside baleen: Exceptional microstructure preservation in a late Miocene whale skeleton from Peru. Geology 2016, 44, 839-842. [CrossRef]

28. Gioncada, A.; Gariboldi, K.; Collareta, A.; Di Celma, C.; Bosio, G.; Malinverno, E.; Lambert, O.; Pike, J.; Urbina, M.; Bianucci, G. Looking for the key to preservation of fossil marine vertebrates in the Pisco Formation of Peru: New insights from a small dolphin skeleton. Andean Geol. 2018, 45, 379-398. [CrossRef]

29. Gioncada, A.; Petrini, R.; Bosio, G.; Gariboldi, K.; Collareta, A.; Malinverno, E.; Bonaccorsi, E.; Di Celma, C.; Pasero, M.; Urbina, M.; et al. Insights into the diagenetic environment of fossil marine vertebrates of the Pisco Formation (late Miocene, Peru) from mineralogical and Sr-isotope data. J. S. Am. Earth Sci. 2018, 81, 141-152. [CrossRef]

30. Bosio, G.; Collareta, A.; Di Celma, C.; Lambert, O.; Marx, F.G.; de Muizon, C.; Gioncada, A.; Gariboldi, K.; Malinverno, E.; Varas-Malca, R.; et al. Taphonomy of marine vertebrates of the Pisco Formation (Miocene, Peru): Insights into the origin of an outstanding Fossil-Lagerstätte. PLOS ONE 2021, 16, e0254395.

31. Boskovic, D.S.; Vidal, U.L.; Nick, K.E.; Esperante, R.; Brand, L.R.; Wright, K.R.; Sandberg, L.B.; Siviero, B.C. Structural and protein preservation in fossil whale bones from the Pisco Formation (middle-Upper miocene), Peru. Palaios 2021, 36, 155-164. [CrossRef]

32. Marty, R.C. Statigraphy and Chemical Sedimentology of Cenozoic Biogenic Sediments from the Pisco and Sechura Basins. Ph.D. Thesis, Rice University, Houston, TX, USA, 1989; p. 268.

33. Di Celma, C.; Malinverno, E.; Bosio, G.; Gariboldi, K.; Collareta, A.; Gioncada, A.; Landini, W.; Pierantoni, P.P.; Bianucci, G. Intraformational unconformities as a record of late Miocene eustatic falls of sea level in the Pisco Formation (southern Peru). J. Maps 2018, 14, 607-619. [CrossRef]

34. Brand, L.R.; Urbina, M.; Chawick, A.; DeVries, T.J.; Esperante, R. A high resolution stratigraphic framework for the remarkable fossil cetacean assemblage of the Miocene/Pliocene Pisco Formation, Peru. J. S. Am. Earth Sci. 2011, 31, 414-425. [CrossRef]

35. Thornburg, T.M.; Kulm, L.D. Sedimentary basins of the Peru continental margin: Structure, stratigraphy, and Cenozoic tectonics from $6^{\circ} \mathrm{S}$ to $16^{\circ} \mathrm{S}$ latitude. Nazca Plate Crustal Form. Andean Converg. 1981, 154, 393-422.

36. Pilger, R.H. Plate reconstructions, aseismic ridges, and low-angle subduction beneath the Andes. Geol. Soc. Am. Bull. 1981, 92, 448-456. [CrossRef]

37. Hsu, J.T. Quaternary uplift of the Peruvian coast related to the subduction of the Nazca Ridge: 13.5 to 15.6 degrees South latitude. Quat. Int. 1992, 15/16, 87-97. [CrossRef]

38. Macharé, J.; Ortlieb, L. Plio-Quaternary vertical motions and the subduction of the Nazca Ridge, central coast of Peru. Tectonophysics 1992, 205, 97-108. [CrossRef] 
39. Hampel, A. The migration history of the Nazca Ridge along the Peruvian active margin: A re-evaluation and some geological implications. Earth Planet. Sci. Lett. 2002, 203, 665-679. [CrossRef]

40. Saillard, M.; Hall, S.R.; Audin, L.; Faber, D.L.; Regard, V.; Herail, G. Andean coastal uplift and active tectonics in southern Peru: Be-10 surface exposure dating of differentially uplifted marine terrace sequences (San Juan de Marcona, similar to 15.4 degrees S). Geomorphology 2011, 128, 178-190. [CrossRef]

41. DeVries, T.J. Oligocene deposition and Cenozoic sequence boundaries in the Pisco Basin (Peru). J. S. Am. Earth Sci. 1998, 11, 217-231. [CrossRef]

42. DeVries, T.J.; Barron, J.A.; Urbina, M.; Ochoa, D.; Esperante, R.; Snee, L.W. The Miocene stratigraphy of the Laberinto area (Río Ica Valley) and its bearing on the geological history of the East Pisco Basin (south-central Peru). J. S. Am. Earth Sci. 2021, 111, 103458. [CrossRef]

43. Malinverno, E.; Bosio, G.; Di Celma, C.; Gariboldi, K.; Gioncada, A.; Pierantoni, P.P.; Collareta, A.; Molli, G.; Bagnoli, G.; Sarti, G.; et al. (Bio)stratigraphic overview and paleoclimatic-paleoceanographic implications of the middle-upper Eocene deposits from the Ica River Valley (East Pisco Basin, Peru). Palaeogeogr. Palaeoclimatol. Palaeoecol. 2021, 578, 110567. [CrossRef]

44. Ochoa, D.; Salas-Gismondi, R.; DeVries, T.J.; Baby, P.; de Muizon, C.; Altamirano, A.; Barbosa-Espitia, A.; Foster, D.A.; Quispe, K.; Cardich, J.; et al. Late Neogene evolution of the Peruvian margin and its ecosystems: A synthesis from the Sacaco record. Int. J. Earth Sci. 2021, 110, 995-1025. [CrossRef]

45. North American Commission on Stratigraphic Nomenclature. North American stratigraphic code. Am. Assoc. Pet. Geol. Bull. 2005, 89, 1547-1591.

46. Ehret, D.J.; MacDaffen, B.J.; Jones, D.S.; DeVries, T.J.; Foster, D.A.; Salas-Gismondi, R. Origin of the white shark Carcharodon (Lamniformes: Lamnidae) based on recalibration of the upper Neogene Pisco Formation of Peru. Palaeontology 2012, 55, 1139-1153. [CrossRef]

47. Gariboldi, K.; Bosio, G.; Malinverno, E.; Gioncada, A.; Di Celma, C.; Villa, I.M.; Urbina, M.; Bianucci, G. Biostratigraphy, geochronology and sedimentation rates of the upper Miocene Pisco Formation at two important marine vertebrate fossil-bearing sites of southern Peru. Newsl. Stratigr. 2017, 50, 417-444. [CrossRef]

48. de Muizon, C. Les Vertébrés de la Formation Pisco (Pérou). Deuxième partie: Les Odontocètes (Cetacea, Mammalia) du Pliocène inférieur de Sud-Sacaco. Trav. De L'inst. Fr. D'études Andin. 1984, 27, 1-188.

49. Marocco, R.; de Muizon, C. Le Bassin Pisco, bassin cénozoïque d'avant arc de la côte du Pérou central: Analyse géodynamique de son remplissage. Géodynamique 1988, 3, 3-19.

50. Ehret, D.J.; Hubbel, G.; MacFadden, B.J. Exceptional preservation of the white shark Carcharodon (Lamniformes, Lamnidae) from the early Pliocene of Peru. J. Vertebr. Paleontol. 2009, 29, 1-13. [CrossRef]

51. Travis, R.B.; Gonzales, G.; Pardo, A. Hydrocarbon Potential of Coastal Basins of Peru. AAPG Bull. 1974, 58, 1460-1461.

52. DeVries, T.J.; Schrader, H. Middle Miocene marine sediments in the Pisco basin (Peru). Boletín De La Soc. Geol. Del Perú 1997, 87, $1-13$.

53. Di Celma, C.; Malinverno, E.; Cantalamessa, G.; Gioncada, A.; Bosio, G.; Villa, I.M.; Gariboldi, K.; Rustichelli, A.; Pierantoni, P.P.; Landini, W.; et al. Stratigraphic framework of the late Miocene Pisco Formation at Cerro Los Quesos (Ica Desert, Peru). J. Maps 2016, 12, 1020-1028. [CrossRef]

54. Di Celma, C.; Malinverno, E.; Gariboldi, K.; Gioncada, A.; Rustichelli, A.; Pierantoni, P.P.; Landini, W.; Bosio, G.; Tinelli, C.; Bianucci, G. Stratigraphic framework of the late Miocene to Pliocene Pisco Formation at Cerro Colorado. J. Maps 2016, 12, 515-529. [CrossRef]

55. Bosio, G.; Gioncada, A.; Malinverno, E.; Di Celma, C.; Villa, I.M.; Cataldi, G.; Gariboldi, K.; Collareta, A.; Urbina, M.; Bianucci, G. Chemical and petrographic fingerprinting of volcanic ashes as a tool for high-resolution stratigraphy of the upper Miocene Pisco Formation (Peru). J. Geol. Soc. 2019, 176, 13-28. [CrossRef]

56. Bianucci, G. Esplorazioni e nuove scoperte nel deserto del Perù: I cetacei fossili di Cerro Colorado e Cerro los Quesos. Quad. Del Mus. Di Stor. Nat. Di Livorno 2010, 23, 3-12.

57. Lisson, C. Los fosfatos de Ocucaje. Boletín De Minas E Ind. De La Constr. 1898, 14, 33-34.

58. Adams, G.I. An outline review of the geology of Peru. Annu. Rep. Smithson. Inst. 1908, 1908, 385-429.

59. Colbert, E.H. A new fossil whale from the Miocene of Peru. Bull. Am. Musem Nat. Hist. 1908, 83, $195-216$.

60. Hoffstetter, R. Un gisement de vertèbrés tertiaires à Sacaco (Sud-Pèrou) témoin Néogène d'une migration de faunes australes au long de la còte occidentale sudaméricaine. Comptes Rendus Hebd. Des Séances De L'académie Des Sci. De Paris Série D 1968, 267, 1273-1276.

61. de Muizon, C. Arctocephalus (Hydrarctos) lomasiensis, subgen. nov. et nov sp., un nouvel Otariidae du Mio-Pliocène de Sacaco. Bull. De L'inst. Fr. D'études Andin. 1978, 7, 169-189.

62. de Muizon, C. Les Vertébrés de la Formation Pisco (Pérou). Première partie: Deux nouveaux Monachinae (Phocidae, Mammalia) du Pliocène de Sud-Sacaco. Trav. De L'inst. Fr. D'études Andin. 1981, 22, 1-160.

63. de Muizon, C. Pliopontos littoralis un nouveau Platanistidae (Cetacea) du Pliocène de la côte péruvienne. Comptes Rendus De L'académie Des Sci. De Paris Ser. II 1983, 296, 625-628.

64. de Muizon, C. Un nouveau Phocoenidae (Cetacea) du Pliocène inférieur du Pérou. Comptes Rendus De L'académie Des Sci. De Paris Ser. II 1983, 296, 1203-1206. 
65. de Muizon, C. Un Ziphiidae (Cetacea) nouveau du Pliocène inférieur du Pérou. Comptes Rendus De L'académie Des Sci. De Paris Ser. II 1983, 297, 85-88.

66. de Muizon, C. Un nouveau Phocoenidae (Odontoceti, Mammalia) du Miocène supérieur de la Formation Pisco (Pérou). Comptes Rendus De L'académie Des Sci. De Paris Ser. II 1986, 303, 1509-1512.

67. de Muizon, C. Walrus-like feeding adaptation in a new cetacean from the Pliocene of Peru. Nature 1993, 365, 745-748. [CrossRef]

68. Pilleri, G. Beiträge Zur Paläontologie Der Cetaceen Perus; Hirnanatomisches Institut: Ostermundingen, Switzerland, 1989; 233p.

69. Kindlimann, R. Selacios del Terciario Tardío de Sacaco, Departamento de Arequipa. Boletín De Lima 1990, 69, 91-95.

70. de Muizon, C.; McDonald, H.G. An aquatic sloth from the Pliocene of Peru. Nature 1995, 375, 224-227. [CrossRef]

71. Kraus, R. The cranium of Piscogavialis jugaliperforatus n.gen., n.sp. (Gavialidae, Crocodylia) from the Miocene of Peru. Paläontologische Z. 1998, 72, 389-405. [CrossRef]

72. de Muizon, C.; Domning, D.P.; Parrish, M. Dimorphic tusks and adaptive strategies in a new species of walrus-like dolphin (Odobenocetopsidae) from the Pliocene of Peru. Comptes Rendus De L'académie Des Sci. De Paris Ser. II 1999, 329, $449-455$. [CrossRef]

73. Stucchi, M.; Urbina, M.; Giraldo, A. Una nueva especie de Spheniscidae del Mioceno tardío de la Formación Pisco. Boletín Del Inst. Fr. De Estud. Andin. 2003, 32, 361-375. [CrossRef]

74. Stucchi, M.; Emslie, S.D.; Varas-Malca, R.M.; Urbina, M. A new late Miocene condor (Aves, Cathartidae) from Peru and the origin of South American Condors. J. Vertebr. Paleontol. 2015, 35, e972507. [CrossRef]

75. Stucchi, M.; Varas-Malca, R.M.; Urbina-Schmitt, M. New Miocene sulid birds from Peru and considerations on their Neogene fossil record in the Eastern Pacific Ocean. Acta Palaeontol. Pol. 2016, 61, 417-427. [CrossRef]

76. Bouetel, V.; de Muizon, C. The anatomy and relationships of Piscobalaena nana (Cetacea, Mysticeti), a Cetotheriidae s.s. from the early Pliocene of Peru. Geodiversitas 2006, 28, 319-395.

77. Chávez-Hoffmeister, M.F.; Stucchi, M.; Urbina, M. El registro de Pelagornithidae (Aves: Pelecaniformes) y la avifauna neógena del Pacífico sudeste. Bull. De L'inst. Fr. D'études Andin. 2007, 33, 175-197. [CrossRef]

78. Göhlich, U.B. The oldest fossil record of the extant penguin genus Spheniscus-A new species from the Miocene of Peru. Acta Palaeontol. Pol. 2007, 52, 285-298.

79. Lambert, O.; Bianucci, G.; Post, K. A new beaked whale (Odontoceti, Ziphiidae) from the Middle Miocene of Peru. J. Vertebr. Paleontol. 2009, 29, 910-922. [CrossRef]

80. Lambert, O.; Bianucci, G.; de Muizon, C. Macroraptorial sperm whales (Cetacea, Odontoceti, Physeteroidea) from the Miocene of Peru. Zool. J. Linn. Soc. 2017, 179, 404-474. [CrossRef]

81. Lambert, O.; Bianucci, G.; Urbina, M.; Geisler, J.H. A new inioid (Cetacea, Odontoceti, Delphinida) from the Miocene of Peru and the origin of modern dolphin and porpoise families. Zool. J. Linn. Soc. 2017, 179, 919-946.

82. Lambert, O.; Collareta, A.; Benites-Palomino, A.M.; Di Celma, C.; de Muizon, C.; Urbina, M.; Bianucci, G. A new small, mesorostrine inioid (Cetacea, Odontoceti, Delphinida) from four upper Miocene localities in the Pisco Basin, Peru. Pap. Palaeontol. 2021, 7, 1043-1064. [CrossRef]

83. Bianucci, G.; Lambert, O.; Post, K. High concentration of long-snouted beaked whales (genus Messapicetus) from the Miocene of Peru. Palaeontology 2010, 53, 1077-1098. [CrossRef]

84. Bianucci, G.; Di Celma, C.; Urbina, M.; Lambert, G. New beaked whales from the late Miocene of Peru and evidence for convergent evolution in stem and crown Ziphiidae (Cetacea, Odontoceti). PeerJ 2016, 4, e2479. [CrossRef] [PubMed]

85. Parham, J.F.; Pyenson, N.D. New sea turtle from the Miocene of Peru and the iterative evolution of feeding ecomorphologies since the Cretaceous. J. Paleontol. 2010, 84, 231-247. [CrossRef]

86. Lambert, O.; de Muizon, C. A new long-snouted species of the Miocene pontoporiid dolphin Brachydelphis and a review of the Mio-Pliocene marine mammal levels in the Sacaco Basin, Peru. J. Vertebr. Paleontol. 2013, 33, 709-721. [CrossRef]

87. Marx, F.G.; Kohno, N. A new Miocene baleen whale from the Peruvian desert. R. Soc. Open Sci. 2016, 2, 160542. [CrossRef]

88. Esperante, R.; Poma, O. Taphonomy and palaeopathology of two mysticete whales, upper Miocene Pisco Formation, Peru. Span. J. Palaeontol. 2015, 30, 1-14.

89. Gariboldi, K.; Gioncada, A.; Bosio, G.; Malinverno, G.; Di Celma, C.; Tinelli, C.; Cantalamessa, G.; Landini, W.; Urbina, M.; Bianucci, G. The dolomite nodules enclosing fossil marine vertebrates in the East Pisco Basin, Peru: Field and petrographic insights into the Lagerstätte formation. Palaeogeogr. Palaeoclimatol. Palaeoecol. 2015, 438, 81-95. [CrossRef]

90. Landini, W.; Altamirano-Sierra, A.; Collareta, A.; Di Celma, C.; Urbina, M.; Bianucci, G. The late Miocene elasmobranch assemblage from Cerro Colorado (Pisco Formation, Peru). J. S. Am. Earth Sci. 2017, 73, 168-190. [CrossRef]

91. Landini, W.; Collareta, A.; Pesci, F.; Di Celma, C.; Urbina, M.; Bianucci, G. A secondary nursery area for the copper shark Carcharhinus brachyurus from the late Miocene of Peru. J. S. Am. Earth Sci. 2017, 78, 164-174. [CrossRef]

92. Bosio, G.; Bracchi, V.A.; Malinverno, E.; Collareta, A.; Coletti, G.; Gioncada, A.; Kočí, T.; Di Celma, C.; Bianucci, G.; Basso, D. Taphonomy of a Panopea Ménard de la Groye, 1807 shell bed from the Pisco Formation (Miocene, Peru). Comptes Rendus Palevol 2021, 20, 119-140.

93. Bosio, G.; Gioncada, A.; Gariboldi, K.; Bonaccorsi, E.; Collareta, A.; Pasero, M.; Di Celma, C.; Malinverno, E.; Urbina, M.; Bianucci, G. Mineralogical and geochemical characterization of fossil bones from a Miocene marine Konservat-Lagerstätte. J. S. Am. Earth Sci. 2021, 105, 102924. [CrossRef] 
94. Di Celma, C.; Pierantoni, P.P.; Malinverno, E.; Collareta, A.; Lambert, O.; Landini, W.; Bosio, G.; Gariboldi, K.; Gioncada, A.; de Muizon, C.; et al. Allostratigraphy and paleontology of the lower Miocene Chilcatay Formation in the Zamaca area, East Pisco basin, southern Peru. J. Maps 2019, 15, 393-405. [CrossRef]

95. Marx, F.G.; Fitzgerald, E.M.; Fordyce, R.E. Like phoenix from the ashes: How modern baleen whales arose from a fossil "dark age". Acta Palaeontol. Pol. 2019, 64, 231-238. [CrossRef]

96. Marx, F.G.; Lambert, O.; de Muizon, C. A new Miocene baleen whale from Peru deciphers the dawn of cetotheriids. R. Sociey Open Sci. 2017, 4, 170560. [CrossRef]

97. Bianucci, G.; Marx, F.G.; Collareta, A.; Di Stefano, A.; Landini, W.; Morigi, C.; Varola, A. Rise of the titans: Baleen whales became giants earlier than thought. Biol. Lett. 2019, 15, 20190175. [CrossRef]

98. Lambert, O.; Bianucci, G.; Post, K. Tusk bearing beaked whales from the Miocene of Peru: Sexual dimorphism in fossil ziphiids? J. Mammal. 2010, 91, 19-26. [CrossRef]

99. Ramassamy, B.; Lambert, O.; Collareta, A.; Urbina, M.; Bianucci, G. Description of the skeleton of the fossil beaked whale Messapicetus gregarius: Searching potential proxies for deep-diving abilities. Foss. Rec. 2018, 21, 11-32. [CrossRef]

100. Kočí, T.; Bosio, G.; Collareta, A.; Sanfilippo, R.; Ekrt, B.; Urbina, M.; Malinverno, E. First report on the cirratulid (Annelida, Polychaeta) reefs from the Miocene Chilcatay and Pisco Formations (East Pisco Basin, Peru). J. S. Am. Earth Sci. 2020, 107, 103042. [CrossRef]

101. Lambert, O.; Bianucci, G.; Beatty, B.L. Bony outgrowths on the jaws of an extinct sperm whale support macroraptorial feeding in several stem physeteroids. Naturwissenschaften 2014, 101, 517-521. [CrossRef]

102. Collareta, A.; Lambert, O.; de Muizon, C.; Benites-Palomino, A.M.; Urbina, M.; Bianucci, G. A new physeteroid from the late Miocene of Peru expands the diversity of extinct dwarf and pygmy sperm whales (Cetacea: Odontoceti: Kogiidae). Comptes Rendus Palevol 2020, 95, 79-100. [CrossRef]

103. Marx, F.G.; Collareta, A.; Gioncada, A.; Post, K.; Lambert, O.; Bonaccorsi, E.; Urbina, M.; Bianucci, G. How whales used to filter: Exceptionally preserved baleen in a Miocene cetotheriid. J. Anat. 2017, 231, 212-220. [CrossRef] [PubMed]

104. Compagno, L.J.V. FAO Species Catalogue. Vol. 4. Sharks of the World. Part 1. Hexanchiformes to Lamniformes. FAO Fish. Synop. 1984, 125, 1-249.

105. Bianucci, G.; Collareta, A.; Bosio, G.; Landini, W.; Gariboldi, K.; Gioncada, A.; Lambert, O.; Malinverno, E.; de Muizon, C.; Varas-Malca, R.; et al. Taphonomy and palaeoecology of the lower Miocene marine vertebrate assemblage of Ullujaya (Chilcatay Formation, East Pisco Basin, southern Peru). Palaeogeogr. Palaeoclimatol. Palaeoecol. 2018, 511, 256-279. [CrossRef]

106. Landini, W.; Collareta, A.; Di Celma, C.; Malinverno, E.; Urbina, M.; Bianucci, G. The early Miocene elasmobranch assemblage from Zamaca (Chilcatay Formation, Peru). J. S. Am. Earth Sci. 2019, 91, 352-371. [CrossRef]

107. Apolín, J.; González, G.; Martínez, J.M. Seláceos del Mioceno Superior de Quebrada Pajaritos (Piura, Perú). In Actas XII Congreso Peruano De Geología; Sociedad Geológica del Perú: Lima, Peru, 2004; pp. 401-404.

108. Schrader, H.; Ronning, P. Diatom biostratigraphy and coastal upwelling interpretation. In Cenozoic Geology of the Pisco Basin; Dunbar, R.B., Baker, P.A., Eds.; IGCP No. 156, Guidebook to Field Workshop; IGCP: Lima, Peru, 1988; pp. $135-140$.

109. Gariboldi, K. A note on diatom stratigraphic markers in upper Miocene sediments of the Pisco Formation, Peru, and description of Delphineis urbinai sp. nov. Diatom Res. 2016, 31, 285-301. [CrossRef]

110. McCurry, M.R.; Pyenson, N.D. Hyper-longirostry and kinematic disparity in extinct toothed whales. Paleobiology 2019, 45, 21-29. [CrossRef]

111. Marocco, R.; de Muizon, C. Los vertebrados del Neogeno de la costa sur del Perú: Ambiente sedimentario y condiciones de fosilización. Bull. De L'inst. Fr. D'études Andin. 1988, 17, 105-117.

112. Collareta, A.; Lambert, O.; de Muizon, C.; Urbina, M.; Bianucci, G. Koristocetus pescei gen. et sp. nov., a diminutive sperm whale (Cetacea: Odontoceti: Kogiidae) from the late Miocene of Peru. Foss. Rec. 2017, 20, 259-278. [CrossRef]

113. Benites-Palomino, A.; Vélez-Juarbe, J.; Salas-Gismondi, R.; Urbina, M. Scaphokogia totajpe, sp. nov., a new bulky-faced pygmy sperm whale (Kogiidae) from the late Miocene of Peru. J. Vertebr. Paleontol. 2019, 39, e1728538. [CrossRef]

114. Collareta, A.; Lambert, O.; Landini, W.; Di Celma, C.; Malinverno, E.; Varas-Malca, R.; Urbina, M.; Bianucci, G. Did the giant extinct shark Carcharocles megalodon target small prey? Bite marks on marine mammal remains from the late Miocene of Peru. Palaeogeogr. Palaeoclimatol. Palaeoecol. 2017, 469, 84-91. [CrossRef]

115. Tarquini, J.; Soibelzon, L.H.; Salas-Gismondi, R.; de Muizon, C. Cyonasua (Carnivora, Procyonidae) from late Miocene of Peru shed light on the early dispersal of carnivorans in South America. J. Vertebr. Paleontol. 2020, 40, e1834406. [CrossRef]

116. Altamirano-Sierra, A. Primer registro de pelícano (Aves: Pelecanidae) para el Mioceno tardío de la formación Pisco, Perú. Bull. De L'inst. Fr. D'études Andin. 2013, 42, 1-12. [CrossRef]

117. Cliff, G.; Dudley, S.F.J. Sharks caught in the protective gill nets off Natal, South Africa. 6. The copper shark Carcharhinus brachyurus (Günther). S. Afr. J. Mar. Sci. 1992, 12, 663-674. [CrossRef]

118. Crawford, R.J.M.; Goya, E.; Roux, J.P.; Zavalaga, C.B. Comparison of assemblages and some life-history traits of seabirds in the Humboldt and Benguela systems. Afr. J. Mar. Sci. 2006, 28, 553-560. [CrossRef]

119. Dudley, S.F.; Cliff, G. Influence of the annual sardine run on catches of large sharks in the protective gillnets off KwaZulu-Natal, South Africa, and the occurrence of the sardine in shark diet. Afr. J. Mar. Sci. 2010, 32, 383-397. [CrossRef]

120. Espinoza, P.; Bertrand, A. Revisiting Peruvian anchovy (Engraulis ringens) trophodynamics provides a new vision of the Humboldt Current system. Prog. Oceanogr. 2008, 79, 215-227. [CrossRef] 
121. Taylor, M.H.; Tam, J.; Blaskovic, V.; Espinoza, P.; Ballón, R.M.; Wosnitza-Mendo, C.; Argüelles, J.; Díaz, E.; Purca, S.; Ochoa, N.; et al. Trophic modeling of the Northern Humboldt Current Ecosystem, Part II: Elucidating ecosystem dynamics from 1995 to 2004 with a focus on the impact of ENSO. Prog. Oceanogr. 2008, 79, 366-378. [CrossRef]

122. Espinoza, P.; Bertrand, A.; van der Lingen, C.D.; Garrido, S.; de Mendiola, B.R. Diet of sardine (Sardinops sagax) in the northern Humboldt Current System and comparison with the diets of clupeoids in this and other eastern boundary upwelling systems. Prog. Oceanogr. 2009, 83, 242-250. [CrossRef]

123. Fréon, P.; Arístegui, J.; Bertrand, A.; Crawford, R.J.; Field, J.C.; Gibbons, M.J.; Tam, J.; Hutchings, L.; Masski, H.; Mullon, C.; et al. Functional group biodiversity in Eastern Boundary Upwelling Ecosystems questions the wasp-waist trophic structure. Prog. Oceanogr. 2009, 83, 97-106. [CrossRef]

124. Galeotti, S.; Von der Heydt, A.; Huber, M.; Bice, D.; Dijkstra, H.; Jilbert, T.; Lanci, L.; Reichart, G.J. Evidence for active El Niño Southern Oscillation variability in the Late Miocene greenhouse climate. Geology 2010, 38, 419-422. [CrossRef]

125. Weiss, T.L.; Denniston, R.F.; Wanamaker, A.D., Jr.; Villarini, G.; von der Heydt, A.S. El Niño-Southern Oscillation-like variability in a late Miocene Caribbean coral. Geology 2017, 45, 643-646. [CrossRef]

126. Peri, E.; Falkingham, P.; Collareta, A.; Bianucci, G. Biting in the Miocene seas: Estimation of the bite force of the macroraptorial sperm whale Zygophyseter varolai using finite element analysis. Hist. Biol. 2021, in press. [CrossRef]

127. Lluch-Belda, D.; Magallón, F.J.; Schwartzlose, R.A. Large fluctuations in the sardine fishery in the Gulf of California: Possible causes. CalCOFI Rep. 1986, 27, 136-140.

128. Hammann, M.G.; Baumgartner, T.R.; Badan-Dangon, A. Coupling of the Pacific sardine (Sardinops sagax caeruleus) life cycle with the Gulf of California pelagic environment. CalCOFI Rep. 1988, 29, 102-109.

129. Hammann, M.G.; Nevárez-Martínez, M.O.; Green-Ruíz, Y. Spawning habitat of the Pacific sardine (Sardinops sagax) in the Gulf of California: Egg and larval distribution 1956-1957 and 1971-1991. CalCOFI Rep. 1998, 39, 169-179.

130. Cisneros-Mata, M.A.; Nevárez-Martínez, M.O.; Hammann, M.G. The rise and fall of the Pacific sardine, Sardinops sagax caeruleus Girard, in the Gulf of California, Mexico. CalCOFI Rep. 1995, 36, 136-143.

131. Bianucci, G.; Landini, W. Killer sperm whale: A new basal physeteroid (Mammalia, Cetacea) from the Late Miocene of Italy. Zool. J. Linn. Soc. 2006, 148, 103-131. [CrossRef]

132. Lambert, O.; Bianucci, G. How to break a sperm whale's teeth: Dental damage in a large Miocene physeteroid from the North Sea Basin. J. Vertebr. Paleontol. 2019, 39, e1660987. [CrossRef]

133. Peri, E.; Collareta, A.; Bianucci, G. A new record of Physeteroidea from the upper Miocene of the Pietra leccese (southern Italy): Systematics, paleoecology and taphonomy of a fossil macroraptorial sperm whale. Riv. Ital. Di Paleontol. E Stratigr. 2020, 126, 751-769.

134. Corkeron, P.J.; Connor, R.C. Why do baleen whales migrate? Mar. Mammal Sci. 1999, 15, 1228-1245. [CrossRef]

135. Rice, D.W. Sperm whale Physeter macrocephalus Linnaeus, 1758. In Handbook of Marine Mammals; Ridgway, S.H., Harrison, R., Eds.; Academic Press: London, UK, 1989; Volume 4, pp. 177-233.

136. Caldwell, D.K.; Caldwell, M.C. Pygmy sperm whale Kogia breviceps (de Blainville, 1938); dwarf sperm whale Kogia simus Owen, 1866. In Handbook of Marine Mammals. River Dolphins and the Larger Toothed Whales; Ridgway, S.H., Harrison, R., Eds.; Academic Press: London, UK, 1989; Volume 4, pp. 235-260.

137. Berta, A.; Lanzetti, A. Feeding in marine mammals: An integration of evolution and ecology through time. Palaeontol. Electron. 2020, 23, a40.

138. Perez, V.J.; Leder, R.M.; Badaut, T. Body length estimation of Neogene macrophagous lamniform sharks (Carcharodon and Otodus) derived from associated fossil dentitions. Palaeontol. Electron. 2021, 24, a09.

139. Shimada, K. The size of the megatooth shark, Otodus megalodon (Lamniformes: Otodontidae), revisited. Hist. Biol. 2021, 33, 904-911. [CrossRef]

140. Purdy, R.W. Paleoecology of fossil white sharks. In Great White Sharks: The Biology of Carcharodon Carcharias; Klimley, A.P., Ainley, D.G., Eds.; Academic Press: San Diego, CA, USA, 1996; pp. 67-78.

141. Godfrey, S.J.; Altman, J. A Miocene cetacean vertebra showing a partially healed compression fracture, the result of convulsions or failed predation by the giant white shark, Carcharodon megalodon. Jeffersoniana 2005, 16, 1-12.

142. Aguilera, O.A.; García, L.; Cozzuol, M.A. Giant-toothed white sharks and cetacean trophic interaction from the Pliocene Caribbean Paraguaná Formation. Paläontol. Z. 2008, 82, 204-208. [CrossRef]

143. Martin, J.E.; Tacail, T.; Adnet, S.; Girard, C.; Balter, V. Calcium isotopes reveal the trophic position of extant and fossil elasmobranchs. Chem. Geol. 2015, 415, 118-125. [CrossRef]

144. Compagno, L.J.V. Alternative life-history styles of cartilaginous fishes in time and space. Environ. Biol. Fishes 1990, $28,33-75$. [CrossRef]

145. Marx, F.G.; Fordyce, R.E. Baleen boom and bust: A synthesis of mysticete phylogeny, diversity and disparity. R. Soc. Open Sci. 2015, 2, 140434. [CrossRef] [PubMed]

146. Slater, G.J.; Goldbogen, J.A.; Pyenson, N.D. Independent evolution of baleen whale gigantism linked to Plio-Pleistocene ocean dynamics. Proc. R. Soc. B Biol. Sci. 2017, 284, 20170546. [CrossRef]

147. McSweeney, F.; Buckeridge, J. The Fossils of the Urban Sanctuary: Rickett's Point Victoria 3193; Greypath Productions: Cheltenham, Australia, 2017; 100p. 
148. Boessenecker, R.W.; Ehret, D.J.; Long, D.J.; Churchill, M.; Martin, E.; Boessenecker, S.J. The Early Pliocene extinction of the mega-toothed shark Otodus megalodon: A view from the eastern North Pacific. PeerJ 2019, 7, e6088. [CrossRef] [PubMed]

149. Govender, R. Early Pliocene fossil cetaceans from Hondeklip Bay, Namaqualand, South Africa. Hist. Biol. 2021, 33, 574-593. [CrossRef]

150. Pimiento, C.; MacFadden, B.J.; Clements, C.F.; Varela, S.; Jaramillo, C.; Velez-Juarbe, J.; Silliman, B.R. Geographical distribution patterns of Carcharocles megalodon over time reveal clues about extinction mechanisms. J. Biogeogr. 2016, 43, 1645-1655. [CrossRef]

151. Pimiento, C.; Griffin, J.N.; Clements, C.F.; Silvestro, D.; Varela, S.; Uhen, M.D.; Jaramillo, C. The Pliocene marine megafauna extinction and its impact on functional diversity. Nat. Ecol. Evol. 2017, 1, 1100-1106. [CrossRef] [PubMed]

152. Carrillo-Briceño, J.D.; Luz, Z.; Hendy, A.; Kocsis, L.; Aguilera, O.; Vennemann, T. Neogene Caribbean elasmobranchs: Diversity, paleoecology and paleoenvironmental significance of the Cocinetas Basin assemblage (Guajira Peninsula, Colombia). Biogeosciences 2019, 16, 33-56. [CrossRef]

153. Sorenson, L.; Santini, F.; Alfaro, M.E. The effect of habitat on modern shark diversification. J. Evol. Biol. 2014, $27,1536-1548$. [CrossRef]

154. Amiot, R.; Göhlich, U.B.; Lécuyer, C.; de Muizon, C.; Cappetta, H.; Fourel, F.; Héran, M.-A.; Martineau, F. Oxygen isotope compositions of phosphate from Middle Miocene-Early Pliocene marine vertebrates of Peru. Palaeogeogr. Palaeoclimatol. Palaeoecol. 2008, 264, 85-92. [CrossRef]

155. Teh, L.S.; Teh, L.C.; Sumaila, U.R. A global estimate of the number of coral reef fishers. PLoS ONE 2013, 8, e65397. [CrossRef]

156. Cione, A.L.; Cabrera, D.A.; Barla, M.J. Oldest record of the great white shark (Lamnidae, Carcharodon; Miocene) in the Southern Atlantic. Geobios 2012, 45, 167-172. [CrossRef]

157. Parrish, R.H.; Serra, R.; Grant, W.S. The monotypic sardines, Sardina and Sardinops: Their taxonomy, distribution, stock structure, and zoogeography. Can. J. Fish. Aquat. Sci. 1989, 46, 2019-2036. [CrossRef]

158. Oyanadel-Urbina, P.; De Gracia, C.; Carrillo-Briceño, J.D.; Nielsen, S.N.; Flores, H.; Casteletto, V.; Kriwet, J.; Rivadeneira, M.; Villafaña, J.A. Neogene Bony Fishes from the Bahía Inglesa Formation, Northern Chile. Ameghiniana 2021, 58, 345-368. [CrossRef]

159. Pyenson, N.D.; Gutstein, C.S.; Parham, J.F.; Le Roux, J.P.; Chavarría, C.C.; Little, H.; Metallo, A.; Rossi, V.; Valenzuela-Toro, A.M.; Velez-Juarbe, J.; et al. Repeated mass strandings of Miocene marine mammals from Atacama Region of Chile point to sudden death at sea. Proc. R. Soc. B Biol. Sci. 2014, 281, 20133316. [CrossRef] 